\title{
Magnetostratigraphy and stable isotope stratigraphy of the middle-Eocene succession of the Ainsa basin (Spain): New age constraints and implications for sediment delivery to the deep waters
}

\author{
Charlotte Läuchli ${ }^{\text {a, }{ }^{*}, 1}$, Miguel Garcés ${ }^{\mathrm{b}}$, Elisabet Beamud ${ }^{\mathrm{c}}$, Luis Valero ${ }^{\mathrm{a}}$, Louis Honegger ${ }^{\mathrm{a}}$, \\ Thierry Adatte $^{\mathrm{e}}$, Jorge E. Spangenberg ${ }^{\mathrm{e}}$, Julian Clark ${ }^{\mathrm{f}}$, Cai Puigdefàbregas ${ }^{\mathrm{b}}$, Andrea Fildani ${ }^{\mathrm{g}}$, \\ Eric de Kaenel ${ }^{\mathrm{h}}$, Teodoro Hunger ${ }^{\mathrm{a}}$, Andres Nowak ${ }^{\mathrm{a}}$, Sébastien Castelltort ${ }^{\mathrm{a}}$

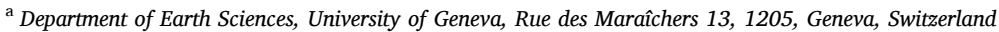 \\ ${ }^{\mathrm{b}}$ Department of Earth and Ocean Dynamics \& Geomodels Research Institute, Universitat de Barcelona, Martí $i$ Franquès, s/n, 08028, Barcelona, Spain \\ ' Paleomagnetic Laboratory CCiTUB-ICTJA, Institut "Jaume Almera", C/ Solé i Sabarís s/n, 08028, Barcelona, Spain \\ ${ }^{\mathrm{e}}$ Faculty of Geosciences and Environment, University of Lausanne, Géopolis, CH-1015, Lausanne, Switzerland \\ ${ }^{\mathrm{f}}$ Equinor Research Center, Austin, TX, USA \\ ${ }^{\mathrm{g}}$ The Deep Time Institute, P.O. Box 27552, Austin, TX, 78755-7552, USA \\ ${ }^{\mathrm{h}}$ DeKaenel Paleo-Research, Mont-sur-Rolle, Switzerland
}

\section{A R T I C L E I N F O}

\section{Keywords:}

Chronostratigraphy

Magnetostratigraphy

Stable isotopes

Deep marine

Sequence stratigraphy

Eustatism

\begin{abstract}
A B S T R A C T
Stratigraphic cycles preserved in sedimentary successions are controlled by the interaction of tectonics, climate, sediment supply and sea-level variations. Understanding the influence of these drivers on sedimentary systems dynamics is crucial to understand and extract information from sedimentary archives. In the deep marine deposits of the Ainsa foreland basin (lower to middle Eocene, southern central Pyrenees, Spain), the origin of wellpreserved cyclicity between channelized sandy submarine fans and hemipelagic deposits remains subject to debate because of the absence of chronostratigraphic constraints on high resolution geochemical proxies. Here, we contrast a combination of newly acquired and legacy geochemical datasets (carbon and oxygen stable isotopes, organic matter content, major and trace elements and the mineralogical composition of bulk hemipelagic sediments) tuned by a new age model to global "target" curves to discuss the possible drivers of the stratigraphic cycles found in the deep marine sediment gravity flow deposits of the Hecho Group. Our new age model is based on magnetostratigraphic and biostratigraphic datasets acquired on a composite section going from the Banaston system to the distal deposits of the Sobrarbe deltaic complex. Four major polarity zones are identified in the studied succession covering the time span from C21n (lower members of the Banaston system) to C19r (Sobrarbe deltaic complex). Our age model is corroborated by the identification of the nannoplankton zone NP16 in the Guaso system (C20n).

Comparison between global carbon isotope curve and local isotope dataset shows some differences, suggesting the preservation of a local isotope signal modulated by eustatism, changes in the environment of deposition and/ or restriction in water circulation in the Ainsa basin. Yet, comparison of the stratigraphic record with global sealevel curves highlights that sands are mainly delivered to the basin during lowstands, pointing to the important role of eustasy even in an active foreland tectonic context. The exception to the rule is the Banaston member II, whose deposition during a sea-level highstand seems to be controlled by the growth of tectonic structures.
\end{abstract}

\section{Introduction}

Stratigraphic cycles that characterize sedimentary records can be detected in depositional environments from continental to deep marine sinks worldwide. According to sequence stratigraphy, sedimentary deposition is driven, through modulation of accommodation and

\footnotetext{
* Corresponding author.

E-mail address: charlotte.laeuchli@fu-berlin.de (C. Läuchli).

1 currently at Institute of Geological Sciences, Freie Universität Berlin, 12249 Berlin, Germany.
} 
sediment supply, by the interaction of (1) global sea-level and eustatic variations related to climate and global tectonics, (2) local/regional tectonics, and/or (3) sediment supply (itself linked to global climate and tectonics) (e.g., Schlager, 1993; Castelltort and Van Den Driessche, 2003; Covault and Graham, 2010; Romans et al., 2016). Thus, sedimentary records contain crucial information regarding past climate and environmental signals. Deep marine environments are perfect targets to study these signals since large volumes of sediment are continuously deposited in submarine fans where the preservation potential is high (Hessler and Fildani, 2019).

In deep marine siliciclastic environments, cyclic patterns can be detected in the alternation of coarse sediment deposits forming submarine fans and low energy hemipelagic environments (e.g., Weltje and de Boer, 1993). The drivers of these pulses of coarse sediments remain a question mark in the study of deep-sea successions. Sands delivered to slope, base of slope and deeper basin environments are traditionally linked to sea-level lowstands (Vail et al., 1977; Posamentier and Vail, 1988). However, new models have been proposed in which sands are delivered to deep water at all sea-level stands (e.g., Covault et al., 2007; Castelltort et al., 2017). A better understanding of the drivers of deep-sea sedimentation and the role of sea-level changes in these processes is thus necessary given the source-rock/reservoir nature of deep-water sand-shale alternations (Bouma et al., 1985; Piper and Normark, 2001). By its response to sea-level changes, stable carbon isotope ratio is an interesting proxy to test independently such relationships (e.g., Jenkyns, 1996).

The Ainsa basin, in the southern central Pyrenees (Spain), is an ideal site to study the drivers of stratigraphic-cyclicity and paleoenvironments over multi-millennial times scales as an entire source to sink system is preserved for the time slice of interest. During the lower to the middle Eocene, the Ainsa deep marine basin is situated between the TrempGraus (fluvio-deltaic sediments) and the Jaca (distal deep marine sediments) basins (Fig. 1; Clark et al., 2017). This basin is filled by very well preserved syn-tectonic sediments typical of a proximal deep basin with submarine fans and hemipelagic deposits of slope, base of slope and basin floor environments. The Ainsa succession is made of eight major
Sediment Gravity Flow (SGF) systems, including Fosado, Los Molinos, Arro, Gerbe, Banaston, Ainsa, Morillo and Guaso (terminology after Mutti, 1983 and Pickering and Bayliss, 2009, Figs. 3 and 4). SGF systems were deposited during Ypresian and Lutetian (lower to middle Eocene) ages (Bentham and Burbank, 1996; Pickering and Corregidor, 2005; Payros et al., 2009; Castelltort et al., 2017; Cantalejo et al., 2020a).

The sand-shale packages of the Ainsa basin have been extensively described and studied (e.g., Mutti, 1983; Mutti et al., 1985; Remacha and Fernández, 2003; Pickering and Corregidor, 2005; Heard and Pickering, 2008; Heard et al., 2008; Pickering and Bayliss, 2009; Pohl and McCann, 2014; Cantalejo and Pickering, 2014, 2015; Scotchman et al., 2015a; Clark et al., 2017; Castelltort et al., 2017; Cantalejo et al., 2020a) but one of the main issues in deciphering the relative roles of external forces on stratigraphic records remains the availability of a robust chronostratigraphic framework that could be used to tune geochemical proxies in the basin. From Fosado to Banaston SGF systems, Castelltort et al. (2017) noted that the stratigraphic cycles detected in the Ainsa basin have periodicities of approximately $1 \mathrm{Myr}$ (Million year). In Castelltort et al. (2017), the Fosado, Gerbe, and Banaston sandy systems are interpreted as being controlled by eustasy and deposited during sea-level lowstands. The age of the Arro system is poorly constrained and the connection with eustatism remains difficult. In Castelltort et al. (2017), the Arro system was linked to enhanced sediment supply during a sea-level highstand. Detrital zircon (U-Th)/He ages for the Arro sandy system support the hypothesis of short-frequency tectonic or climatic pulse during the deposition of this system (Thomson et al., 2017). More recently, nannofossil Subzone NP14a was identified in the Arro SGF system that could be associated with both sea-level highstand or lowstand (Cantalejo et al., 2020a). From Banaston to Guaso SGF systems, the relationship between sea-level, sediment supply, tectonic and climatic modulations causing siliciclastic deposition in the deep marine environment remain poorly known and acknowledged.

The main tasks of this study were to (1) improve the chronostratigraphic constraints on the studied succession, (2) tune newly acquired geochemical proxies (e.g., stable carbon isotopes), (3) discuss the response of these proxies to eustatism, (4) test the relationship between

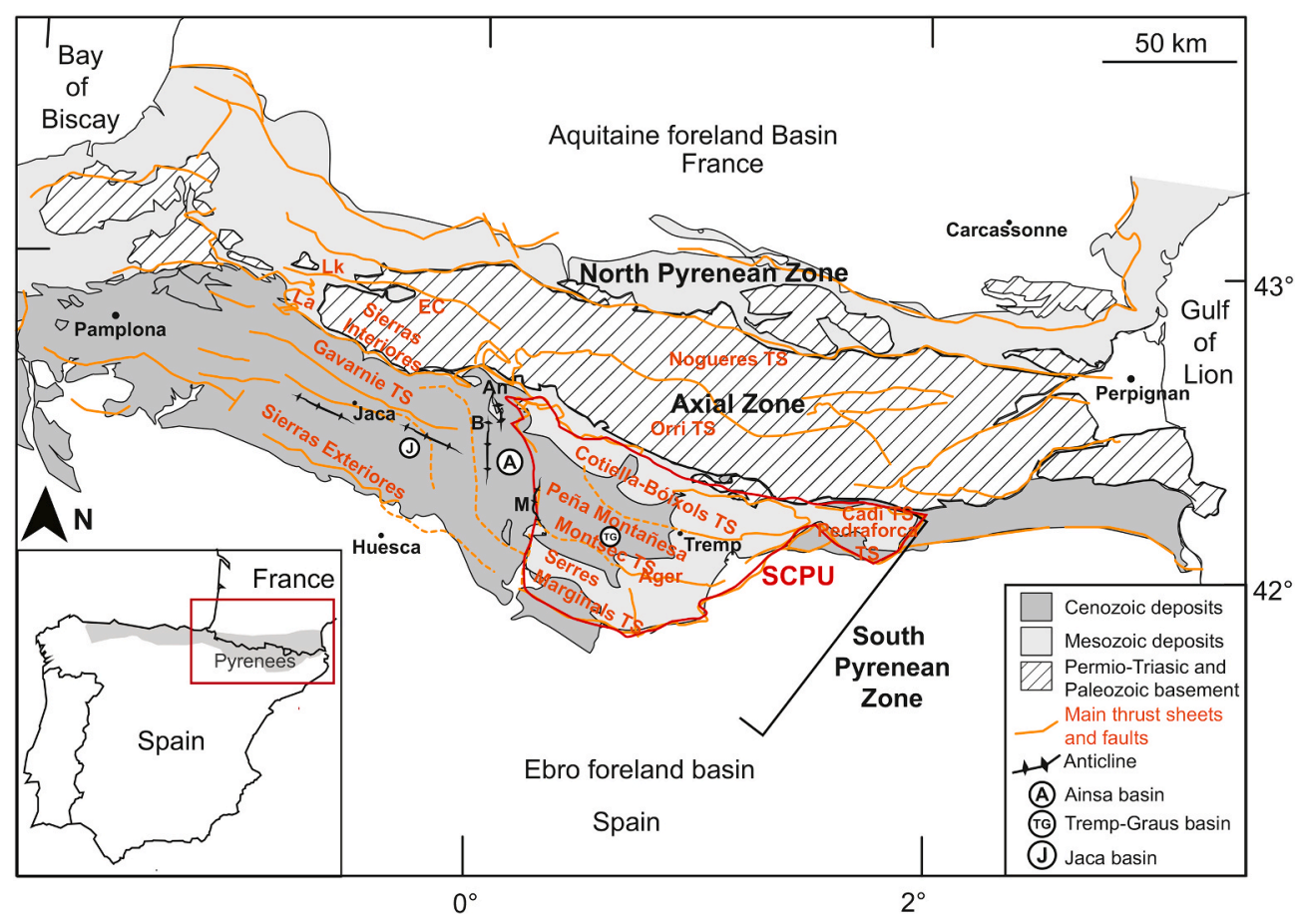

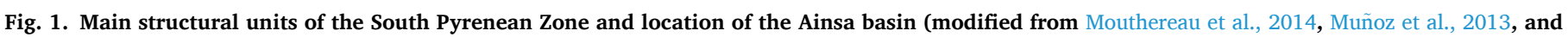

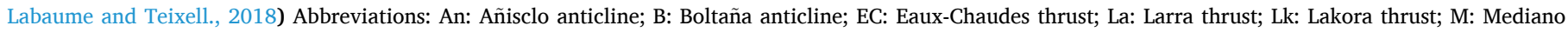
anticline; SCPU: South-Central Pyrenean Unit; TS:Thrust Sheet. 
eustatism and deep marine sedimentation. Several studies and age models based mainly on biostratigraphy (Jones et al., 2005; Pickering and Corregidor, 2005; Scotchman et al., 2015a) and magnetostratigraphy (Holl and Anastasio, 1993; Bentham and Burbank, 1996; Mochales et al., 2012a; Cantalejo et al., 2020a) exist in the Ainsa basin. To build on these existing datasets, two approaches were used conjointly: magnetostratigraphy and biostratigraphy. Magnetostratigraphy provides accurate time lines by means of correlation with the Geomagnetic Polarity Time Scale, but needs the support of external age constraints provided here by established magnetostratigraphies in neighboring successions and biostratigraphy. The new chronostratigraphic constraints were used to tune the geochemical records generated. Stable isotopes were secondly compared to target global curves tied to accurate age models (e.g., sea-level curves of Miller et al., 2005 and Kominz et al., 2008, global carbon and oxygen isotope records of Cramer et al., 2009 and Zachos et al., 2001) in order to test the relationship between eustatism, carbon isotope ratios and deep marine sedimentation.

Magnetostratigraphy and isotope analyses were performed on three sections (Labuerda, Forcaz, and Morillo de Tou; Figs. 4, 6 and 7) in the deep marine sediments of the Ainsa basin. New and existing biostratigraphic data were used to calibrate and complement the magnetostratigraphy. With existing records in Castelltort et al. (2017), this dataset provides a new chronostratigraphic framework for a near-complete profile in the Ainsa basin deep marine succession. In addition, we provide data on the total organic carbon content, the elemental, and the mineralogical composition of bulk sediments to constrain environmental conditions in the system.

\section{Geological setting}

\subsection{The pyrenean orogeny and the south pyrenean peripheral basins}

The formation of the Pyrenean mountain range began in the late Santonian (upper Cretaceous, age, $\sim 84 \mathrm{Ma}$ ) with the asymmetric collision and partial subduction of the Iberian plate below the Eurasian one (Muñoz, 1992; Roure and Chourkroune, 1998; Beaumont et al., 2000; Fillon and van der Beek, 2012; Mouthereau et al., 2014). The Pyrenees are conventionally subdivided in three structural zones, (1) the Axial Zone formed by an antiformal stack of Paleozoic basement, (2) the retro-wedge and foreland basins of the Northern Pyrenean Zone, and (3) the pro-wedge and foreland basins of the Southern Pyrenean Zone (Séguret, 1972, Fig. 1). The different phases of deformation associated with the development of this asymmetric mountain range are here described focusing on the Southern Pyrenean Zone. Counterclockwise $\left(\sim 35^{\circ}\right)$ rotation of the Iberian plate (Choukroune, 1992), synchronous with the opening of the Bay of Biscay, led to an extensional rifting context during the early Cretaceous. The extensional system was replaced at the upper Santonian by a stage of inversion tectonics with the reactivation of Mesozoic extensional faults and the development of the firsts Pyrenean thrust sheets (e.g., Cotiella-Bóixols thrust sheet, Muñoz et al., 2013, Fig. 1). Associated foreland basins formed at the front of these thrust sheets were primarily filled by deep marine turbidites deposits (e.g., Vallcarga Formation, Puigdefàbregas et al., 1992). Coeval with the development of the Bóixols thrust sheet, shallow marine successions (Aren Sandstone Formation, Mey et al., 1968) and fluvial and lacustrine deposits (Tremp Group, Pujalte and Schmitz, 2005) were subsequently deposited in the eastern part of the Southern Pyrenean Zone. The asymmetrical collision between the Eurasian and the Iberian plate induced flow toward the WNW with the deposition of deep-water carbonates and siliciclastic sediments in the western part of the Southern Pyrenean Zone (Whitchurch et al., 2011; Thomson et al., 2019). During the Ilerdian stage (early Eocene), a major transgression flooded the southern basins leading to the deposition of the Alveolina Limestone Formation (Puigdefàbregas and Souquet, 1986). From the early to the middle Eocene, the Pyrenees underwent an acceleration of shortening rates and an exhumation of the Axial Zone (Whitchurch et al., 2011; Labaume and Teixell, 2018, Thomson et al., 2019). It led to the compartmentalization of the south Pyrenean basins into several parallel thrust-top structures forming the South-Central Pyrenean Unit (SCPU; parallel thrust sheets from north to south: Cotiella-Bóixols, Peña Montañesa-Montsec, and Sierras Exteriores-Sierras Marginales; Puigdefàbregas et al., 1992, Fig. 1). Geometries and facies distribution amongst the coeval piggy-back basins developed on top of these structures were controlled by the loading of the lithosphere and the emplacement of Mesozoic south verging faults (Puigdefàbregas et al., 1992). The piggy back basin of Tremp, on top of the moderately subsiding hanging wall of the SCPU, was infilled by the fluvio-deltaic deposits of the Montanyana Group (Tremp-Graus basin, Figs. 2 and 3, Puigdefàbregas et al., 1992). The sediments of the prograding fan of the Montanyana Group were transported to the footwall of the Peña Montañesa-Montsec and the Gavarnie thrust systems, filling the distal Ainsa and the Jaca basins respectively (Muñoz et al., 2018, Figs. 1 and 2). The transfer of clastic sediments from proximal to distal environments was allowed by an east to west river drainage system (Nijman and Nio, 1975; Payros et al., 2009) linked to incised canyons (Atiart, Charo-Lascorz, Monclús, and Formigales canyons) and channels along the marine lateral ramp (Clark et al., 2017). In the Ainsa and Jaca basins, the Hecho Group (Mutti, 1983), a succession of deep marine turbidites and hemipelagic deposits was accumulated between growing tectonic structures of the Mediano, Añisclo, and the Boltaña anticlines forming the present-day segmentation between Tremp-Graus, Ainsa, and Jaca basins (Figs. 1 and 2).

The last stage of the development of the South-Central Pyrenean Unit is characterized by a decrease in subsidence rates due to the southward migration of the deformation and a general progradation induced by the development of the Pyrenean Axial Zone antiformal stack (Muñoz, 1992; Sinclair et al., 2005). From the upper Eocene to the Oligocene, successively shallow marine (Sobrarbe deltaic complex, Bartonian stage, Dreyer et al., 1999; Mochales et al., 2012a; Scotchman et al., 2015a) and continental fluvial sediments (Escanilla Formation, Bentham et al., 1992; Michael et al., 2014, Vinyoles et al., 2021) were deposited in the basins. During the late Priabonian, the Tremp-Graus-Ainsa-Jaca basins were disconnected from the Atlantic Ocean, most probably as a consequence of the emplacement of the Basque-Cantabrian units in the west (Costa et al., 2010). The last tectonic activity related to the orogeny of the Pyrenees occurred during the late Oligocene-early Miocene (Puigdefàbregas, 1975; Rosenbaum et al., 2002; Labaume and Teixell, 2018).

\subsection{The Ainsa basin}

The Ainsa basin was developed from Lutetian to Priabonian times (Bentham and Burbank, 1996; Pickering and Corregidor, 2005; Payros et al., 2009; Mochales et al., 2012a; Cantalejo et al., 2020a). Structurally, the basin is defined by its confinement between the lateral ramp of the Peña Montañesa-Montsec to the east, as well as the Gavarnie thrust and Boltaña anticline today to the west (Figs. 1 and 2). As such, the Ainsa basin, open toward the deeper Atlantic waters to the west, was progressively syncline-deformed between three progressively growing anticlines (Mediano, Añisclo and Boltaña, Fig. 2).

The turbiditic succession of interest belongs to the Hecho Group (Mutti et al., 1972) and has been extensively studied (e.g., De Federico, 1981; Mutti et al., 1988; Barnolas and Gil-Peña., 2001; Pickering and Corregidor, 2005; Arbués et al., 2007; Pickering and Bayliss, 2009; Arbués et al., 2011; Pohl and McCann, 2014; Cantalejo and Pickering, 2014; Scotchman et al., 2015a). All studies converge towards the interpretation that the Hecho Group was deposited below the shelf-edge of the Tremp-Graus basin into upper slope to base of slope depositional environments by channels and canyons (Atiart, Charo-Lascorz, and Formigales canyons, Payros et al., 2009). The sediments forming the Hecho Group are composed of interbasinal and extrabasinal carbonates as well as extrabasinal siliciclastic sediments (Gupta and Pickering, 2008). The main source of extrabasinal sediments was the fluvio-deltaic 


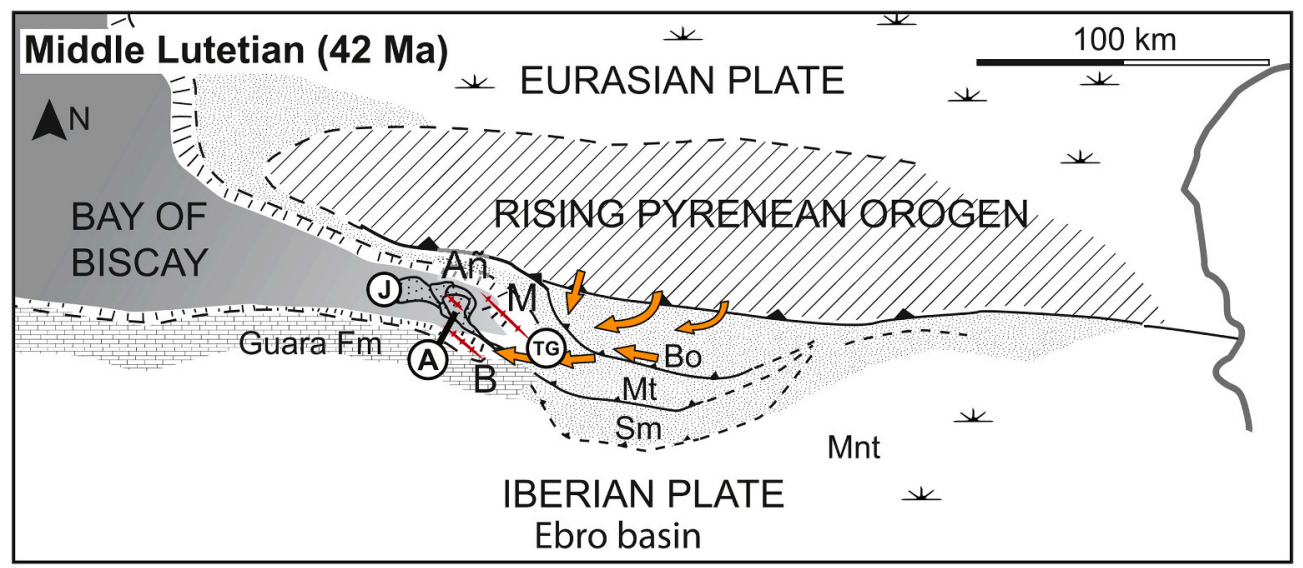

Fig. 2. Paleogeographic reconstitutions of the Ainsa basin in the middle Lutetian (modified from Muñoz et al., 2013 and Castelltort et al., 2017). During the Lutetian, the Ainsa basin is largely underfilled and hosts slope and deep-water deposits of the Hecho Group. This period is also marked by the development of the Boltaña anticline controlling the geometry of the deposition in the basin. Note that the anticline has not rotated yet and is still in its initial position. Abbreviations: Añ: Añisclo anticline; B: Boltaña anticline; M: Mediano anticline; Bo: Cotiella-Bóixols thrust sheet; Mt: Peña Montañesa-Montsech thrust sheet; Sm: Serres Marginales thrust sheet.

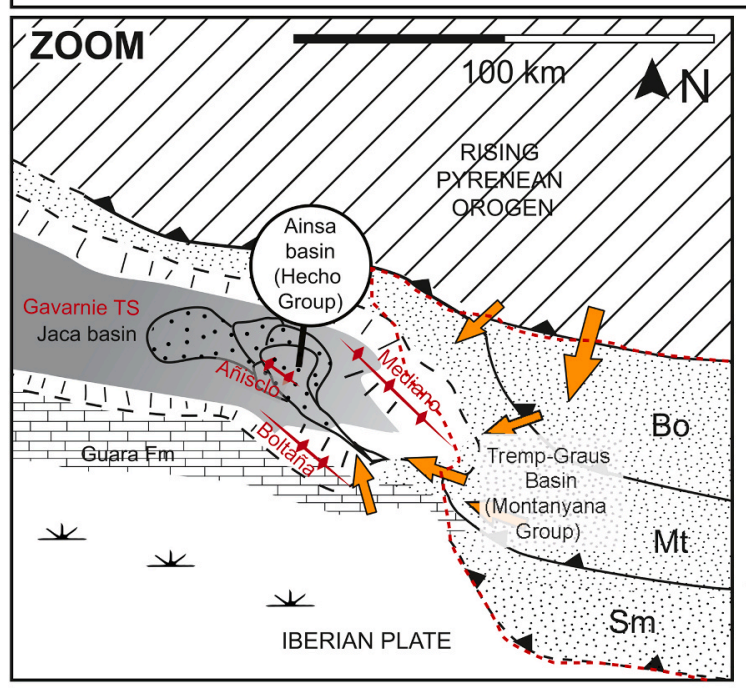

\section{(A) Ainsa basin \\ (TC) Tremp-Graus basin \\ (J) Jaca basin}

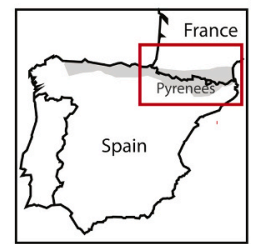

Dominant transport

Deep marine

basin and fans

Silicilastic shelf

and fluvial systems

Carbonate platforms

$\ldots$ Anticlines

South Central Pyrenean

Unit (SCPU)

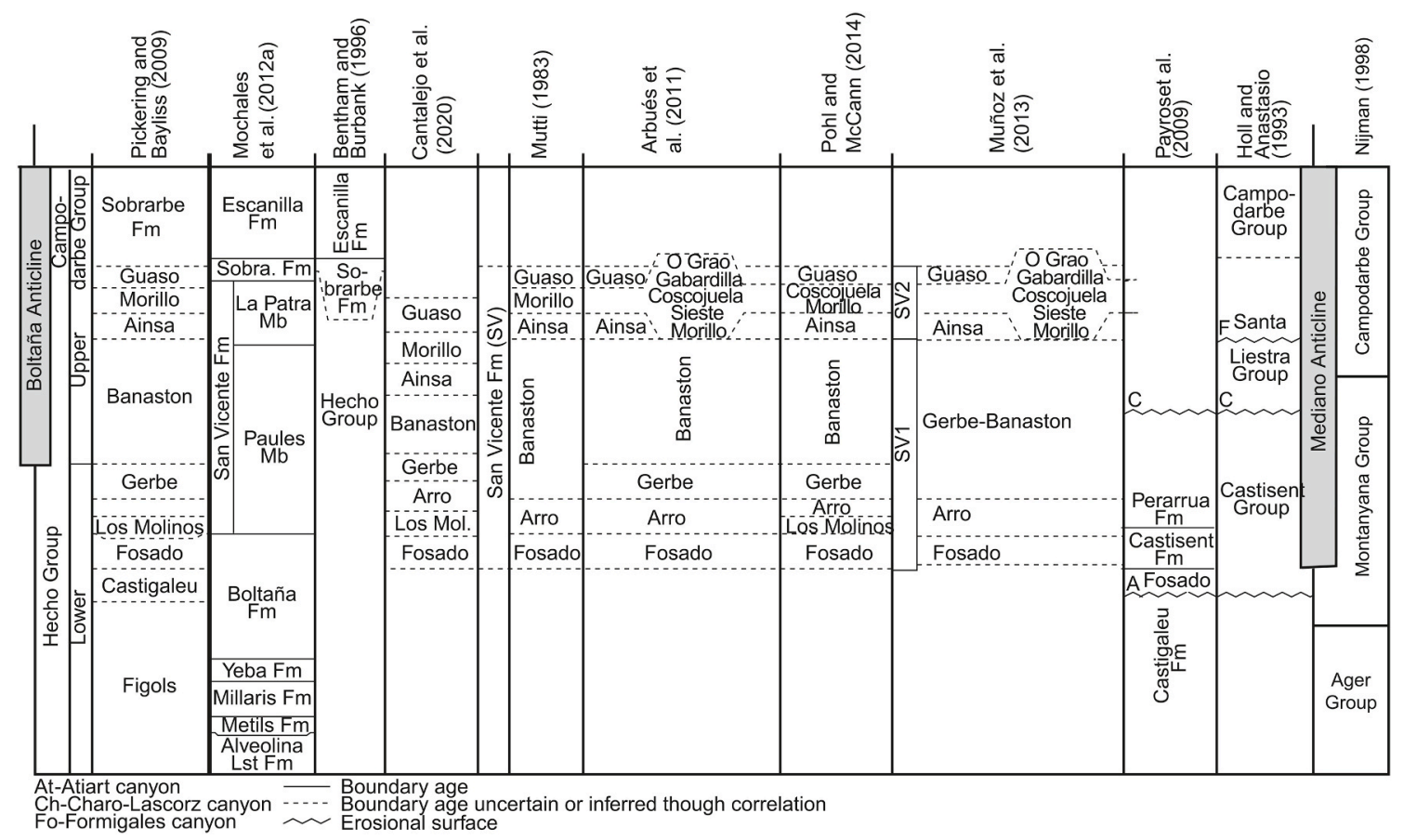

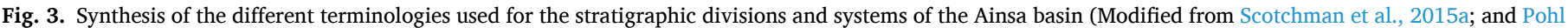
and McCann, 2014). 


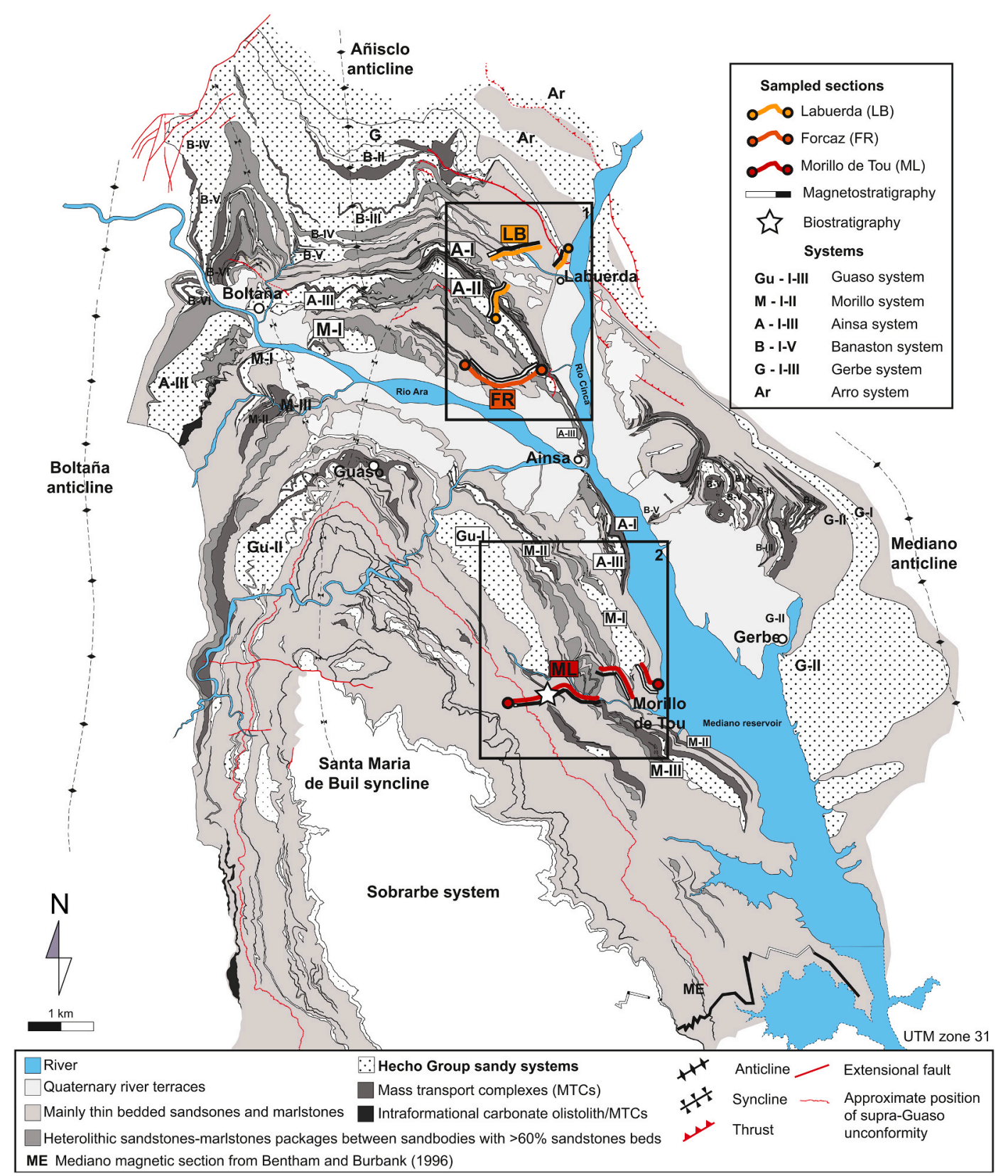

Fig. 4. Geological map of the studied area redrawn from Pickering and Bayliss (2009), Pickering and Cantalejo (2015), and Cornard and Pickering (2019). The sections sampled for magnetostratigraphy and geochemical analyses are indicated on the map (Labuerda, Forcaz, and Morillo de Tou sections). Mediano magnetic section (ME) of Bentham and Burbank (1996) approximate position is also indicated. The studied successions are located on the eastern flank of the Santa Maria de Buil syncline which is also the western flank of the Mediano anticline.

Montanyana Formation (Tremp-Graus system) fed by the uplift of the early Pyrenean reliefs in the north and the Ebro foreland basin in the south (Fig. 2; Gómez-Gras et al., 2016; Thomson et al., 2017).

At first-order, the deep marine stratigraphic series of the Ainsa basin are made of approximatively $4 \mathrm{~km}$ thick syn-tectonic deposits constituted by an alternation of sandy formations, dominated by sediment gravity flow facies forming submarine fans, and marly formations. The latter are interpreted as slope deposits, levees deposits or distal turbidites. In more detail, the Hecho Group in the area of Ainsa is formed by eight subdivisions related to major unconformities and the migration of the axis of deposition of the sandy formations: Fosado, Los Molinos, Arro, Gerbe, Banaston, Ainsa, Morillo, and Guaso Sediment Gravity Flow systems (SGF systems, following the nomenclature of Pickering and Bayliss, 2009, Fig. 3). Each Sediment Gravity Flow system is constituted by two to eight turbiditic sandbodies hundreds of meters thick (Pickering and Bayliss, 2009) deposited between large sequences of slope and hemipelagic marly deposits. Four major truncations are identified in the basin, the Atiart, Charo-Lascorz, Monclús, and Formigales canyons (Payros et al., 2009; Clark et al., 2017).

The deposition of the first sediment system of the Hecho Group in the area of Ainsa (Fosado) was estimated around 51 and $49 \mathrm{Ma}$ (Scotchman et al., 2015a). More precisely, the Atiart canyon located at the base of the Hecho Group deposits was dated between 50.2 and 50.5 Ma (Castelltort et al., 2017; Clark et al., 2017). The deepening of the Ainsa basin was associated with the enhanced subsidence of the footwall of the Peña Montañesa-Montsec trust sheet with respect to the South-Central Pyrenean Unit (Garcés et al., 2020).

The deposition of the lower Hecho Group (Fosado, Los Molinos, and Arro SGF systems) was marked during the late Ypresian by the activation of the thrust system of La Fueba associated with the Peña Montañesa- 
Montsec thrust sheet development. The activation of La Fueba thrust system was coeval with major truncations in the Ainsa basin and induced deformation of the lower Hecho Group (Muñoz et al., 2013). In comparison, the upper Hecho Group (Gerbe, Banaston, Ainsa, Morillo, and Guaso SGF systems) deposited during the Lutetian (Mochales et al., 2012a; Castelltort et al., 2017; Cantalejo et al., 2020a) is less deformed despite the active tectonic evolution of the basin (Pickering and Corregidor, 2005). During the middle Eocene (early Lutetian), the Sobrarbe fold system was developed. The Gavarnie thrust sheet was deformed and the Ainsa basin progressively transformed into a piggy-back basin. Two major anticlines separated by the Santa Maria de Buil syncline (Fig. 4) were formed displaying an ESE-WNW axis (Muñoz et al., 2013, Fig. 2). The Mediano anticline was developed between Tremp-Graus and Ainsa basins from the early Lutetian to the Bartonian (Poblet et al., 1998). The growth of this anticline is associated with the development of the smaller Añisclo anticline (Fernández et al., 2012; Muñoz et al., 2013). The second major anticline of the basin, the Boltaña anticline, is located between the Ainsa and Jaca basins. Its growth, initiated during the middle Lutetian, ended in the early Priabonian (Muñoz et al., 2013). According to Heard et al. (2008), the development of the Boltaña anticline could have led to a partial restriction of water circulations between the Ainsa basin and the open ocean inducing periods of low oxygen levels in the Ainsa basin. As deformation proceeded, the basin underwent a progressive clockwise rotation (Mochales et al., 2012b) of $45^{\circ}-60^{\circ}$ (Muñoz et al., 2013). As a result, paleoflows recorded at the base of the Ainsa basin succession are, at present time, generally oriented towards the NNW but were initially indicating west-oriented sediment transport. In contrast, towards the top of the succession, paleoflows are oriented towards the WNW closer to their initial directions. From the late Lutetian to the Priabonian, the basin was filled and, successively over-filled by the shallow marine Sobrarbe and the fluvial Escanilla Formations (Bentham, 1992; Mochales et al., 2012a).

\section{Material and methods}

A complete stratigraphic succession was sampled from Gerbe to Guaso SGF systems in the Ainsa basin for (1) magnetostratigraphy and (2) high resolution geochemical proxies. Two additional sites were sampled for biostratigraphy to calibrate the magnetostratigraphy (see star, Fig. 4). The succession studied is a compilation of three sub-sections named Labuerda (1000 m), Forcaz (462 m), and Morillo de Tou sections (1083 m, Figs. 4, 6 and 7) correlated on the field by marker units and orthoimages. Stratigraphic thicknesses of the sections were measured with a Jacob staff, and geometric calculations based on field dip and strike data when direct measurements were not possible. The identification of the different SGF systems is based on the geological maps of Pickering and Bayliss (2009), Pickering and Cantalejo (2015), and Cornard and Pickering (2019).

\subsection{Magnetostratigraphy}

The three sections were sampled for magnetostratigraphy (Figs. 4, 6 and 7) with a resolution of $10 \mathrm{~m}$ on average for Labuerda and Forcaz sections and $20 \mathrm{~m}$ on average for the Morillo de Tou section. Such a resolution coupled with a mean sediment accumulation rate of approximately $30 \mathrm{~cm} / \mathrm{kyr}$ in the Ainsa basin (Heard and Pickering, 2008) allows capturing all polarity reversals present in the time span of interest. Paleomagnetic core samples were drilled in fresh mudstone rocks focusing on the finest and less deformed marlstones. Thermal and few additional alternating field progressive demagnetization techniques were carried out on the samples at the Paleomagnetic Laboratory of Barcelona (CCiTUB- ICTJA CSIC; details about the methods can be found in Supplementary material I, S.1.).

\subsection{Biostratigraphy}

For biostratigraphy using nannoplanktons zones, approximately 200 $\mathrm{g}$ of fresh rocks were collected in the finer and less deformed marlstones of two sites of the Morillo de Tou section (Figs. 4 and 8; samples' GPS location in Supplementary material I, S.3).

\subsection{Geochemistry}

Approximately $200 \mathrm{~g}$ of marine carbonate mudstone were collected per site targeting the finer and less deformed hemipelagic deposits at $30-40 \mathrm{~cm}$ below the weathering surface. A spacing of around $10 \mathrm{~m}$ (stratigraphic depth) was applied between samples for each section. All the geochemical analyses were performed at the laboratories of the University of Lausanne. Carbon and oxygen isotopes $\left(\delta^{13} \mathrm{C}\right.$ and $\delta^{18} \mathrm{O}$ values, both expressed in \%o relative to VPDB standard) were measured in whole-rock carbonates (Supplementary material I, S.1.2.5). Major and trace elements (X-ray fluorescence, Supplementary material I, S.1.2.2), mineralogy (X-ray diffraction techniques, Supplementary material I, S.1.2.3), and the organic matter content (Rock-Eval) were determined on whole-rock material (Supplementary material I, S.1.2.4).

\section{Results}

\subsection{Stratigraphy}

The stratigraphic succession sampled comprises grey to dark massive or laminated hemipelagic marlstones alternating with turbiditic sandstones with thickness varying between centimetric to metric scale. The fine-grained sediments show evidence of (1) slides/slumps cohesiveflow deposits of metric scale, (2) typical abyssal zone ichnofossils (Nereites ichnofacies), (3) nummulitic packstones beds of centrimetric scale interpreted as reworked material from nearby carbonate platform deposited in deeper water during storm events (Cantalejo and Pickering, 2014), and (4) dark levels enriched in organic matter. Major SGF systems are characterized by debris flow deposits, erosive sandy channels, and overbank hemipelagic deposits. These major clastic pulses of coarse sediments often show fining-upwards sequences. Off-axis deposits are characterized by marlstones dominant intervals.

\subsubsection{Labuerda section $\left(N 42.456185^{\circ}\right.$ E0.136285 $)$}

The Labuerda section (LB, Fig. 4) begins near the village of Labuerda. It has a stratigraphic thickness of $1000 \mathrm{~m}$. This section begins in the Gerbe system and ends in the off-axis deposits of the Ainsa II submarine fan (A-II in Figs. 4 and 6). The lower part of this section is marked by an unconformity related to the emplacement of a thrust (Fig. 4). The interval above this thrust is composed of very fine marlstones interrupted by heterolithic intervals at approximately $400 \mathrm{~m}$. Based on the map of Pickering and Bayliss (2009), we interpret this marlstone interval as the lateral equivalent of the Banaston SGF system (Fig. 4). Due to the paucity of sandy beds in the sampled section, uncertainty is high in the identification of the second member (BII) of the Banaston SGF lateral deposits. This member is therefore indicated with a question mark in this study (B-II?, Fig. 6). At $879.5 \mathrm{~m}$, the section reaches Ainsa I SGF sandbodies (A-I in Figs. 4 and 6). The Labuerda section eventually ends in the overbank deposits of Ainsa II (AII, Fig. 6). Slumps are present at the base and in the upper part of the section (Fig. 5A). The Labuerda section is marked by two darker beds around $210 \mathrm{~m}$ and $920 \mathrm{~m}$ and a nummulitic bed around $970 \mathrm{~m}$ (Fig. 6).

\subsubsection{Forcaz section $\left(N 42.433169^{\circ}\right.$ E0.126997 $)$}

The Forcaz section (FR, Fig. 4) localized near the Forcaz stream begins at the base of Ainsa II SGF system (A-II, Fig. 4). It overlaps Labuerda section (LB) with LB102 sample (Labuerda section) correlated to FR001 sample (Forcaz section, based on a lateral mapping of strata). This section of $462 \mathrm{~m}$ thickness begins at the base of Ainsa II SGF sandy package. 

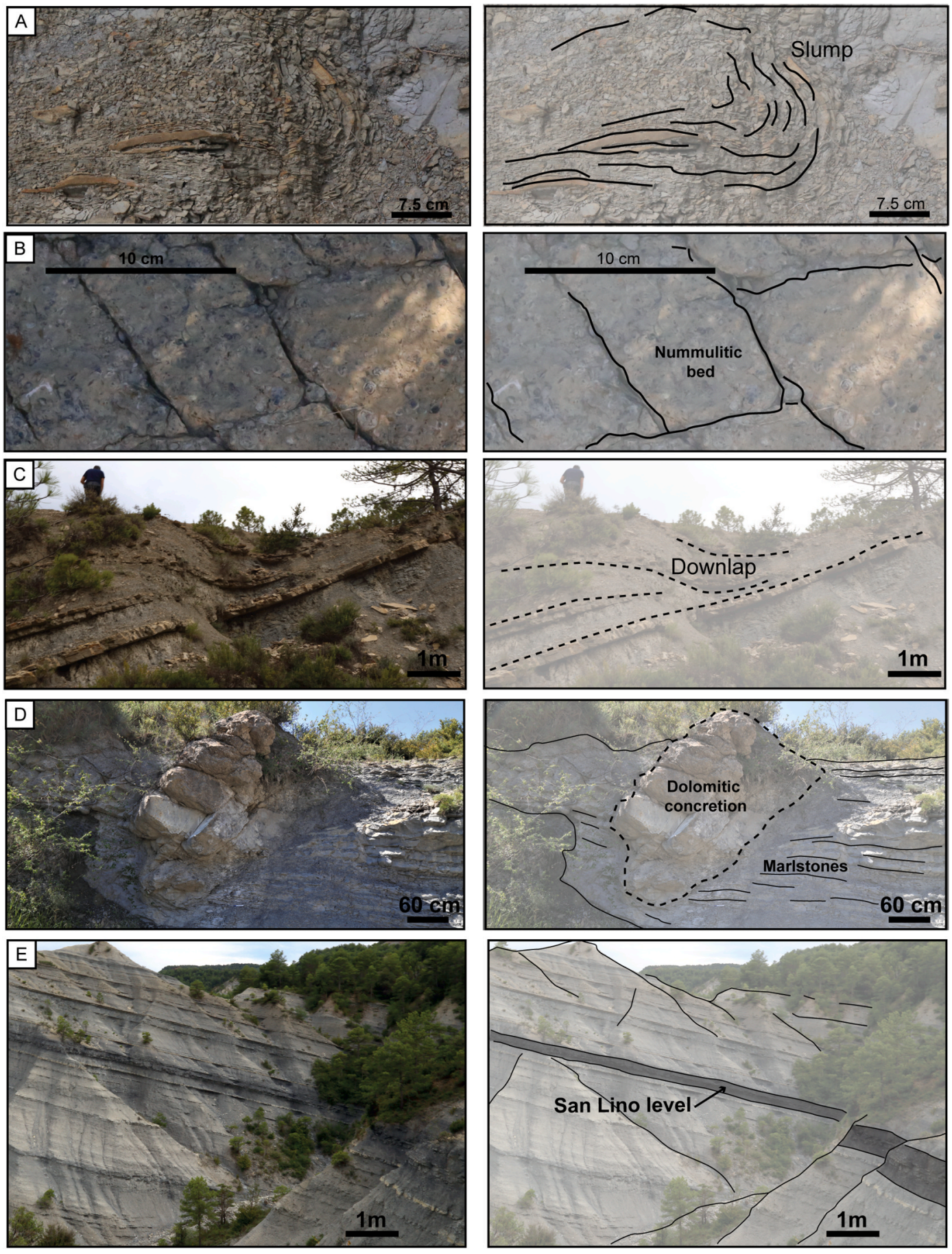

Fig. 5. Interpreted field photographs from Labuerda, Forcaz andMorillo de Tou sections (A) Slumps in the Labuerda section (at $900 \mathrm{~m}$ ). (B) Nummulitic bed in the Forcaz section (around 340m). (C) Downlap geometry on erosive surface suggesting slump scar. (D) Dolomitic concretions. (E) San Lino level with typical alternance of marlstones and isolated sandy beds.

A fining-upward sequence is observable at the top of Ainsa II sandbodies followed by a hemipelagic dominant interval of approximately $200 \mathrm{~m}$ in stratigraphic thickness (from $78 \mathrm{~m}$ to $287.5 \mathrm{~m}$, Forcaz section, Fig. 6). At the top of Forcaz section, heterolithic beds are interpreted as belonging to Morillo I overbanks deposits (M-I, Figs. 4 and 6). Two darker levels mark the Forcaz section at approximately $200 \mathrm{~m}$ and $260 \mathrm{~m}$, and a nummulitic bed occurs around $340 \mathrm{~m}$ (Figs. 5B and 6).

\subsubsection{Morillo de tou section (N42.377686 E0.156158 ${ }^{\circ}$}

The Morillo de Tou section (ML, Fig. 4) begins near the namesake village, $6.5 \mathrm{~km}$ far from the former Forcaz section, and has a thickness of
$1129 \mathrm{~m}$. It begins in the marly interval between Ainsa and Morillo SGF systems. Correlation with the Forcaz section based on orthoimages places the base of the Morillo de Tou section approximately $10 \mathrm{~m}$ above the top of the Forcaz section, which is corroborated later in this paper by the consistency of isotopic values across both sections. The Morillo de Tou section crosses Morillo I sandbodies (M-I, Fig. 4) rich in large forms of benthic foraminifers and various bioclasts, Morillo II-III (M-II, M-III), and Guaso I-II (G-I, G-II) overbank deposits (Fig. 7). Three intervals are notable in this section. First, an interval of massive marlstones of approximately $40 \mathrm{~m}$ is found between 720 and $760 \mathrm{~m}$ (Figs. 7 and 9). It is punctually characterized by centimetric scale darker beds $(\sim 10 \mathrm{~cm}$ and 

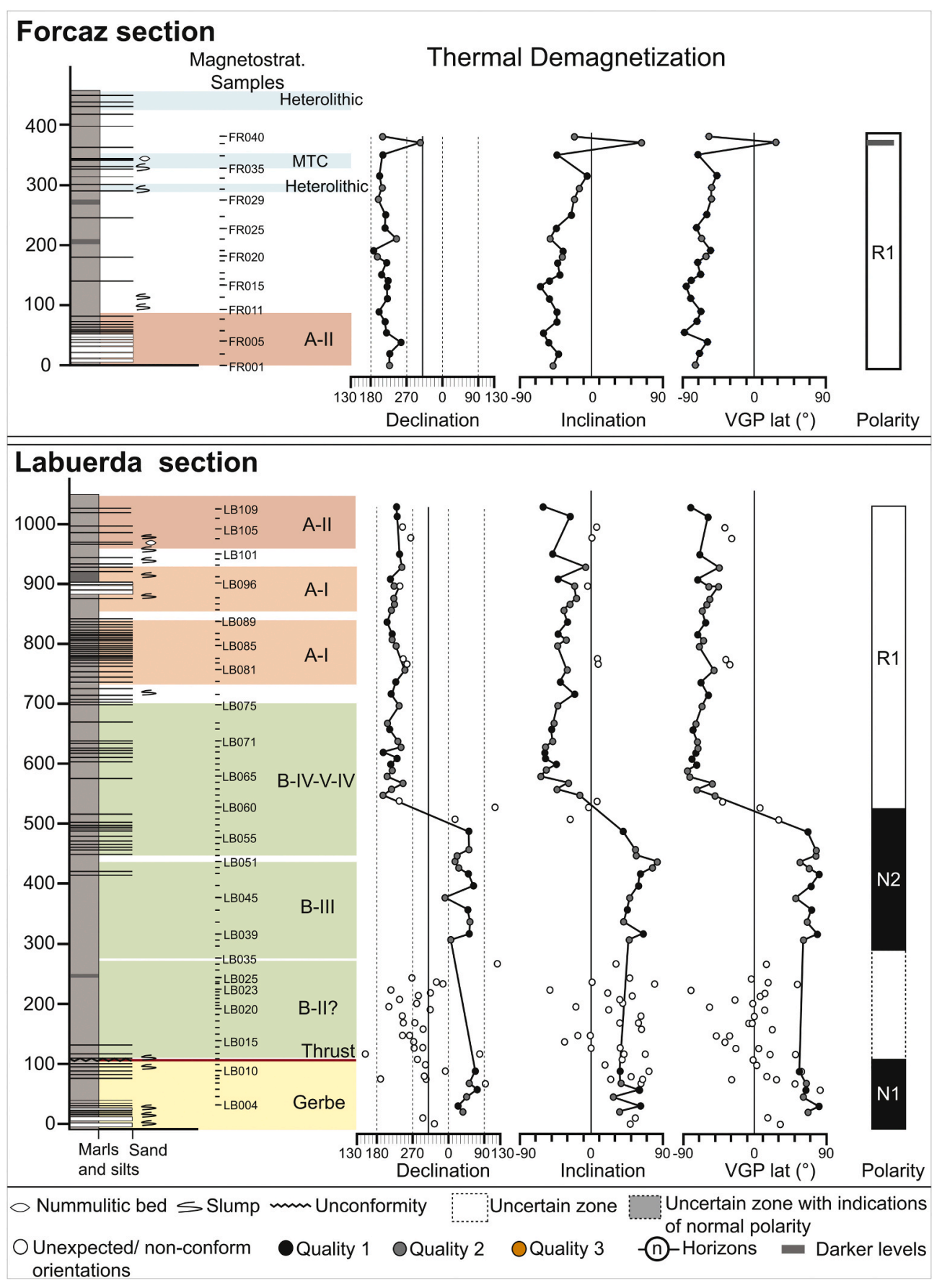

Fig. 6. Stratigraphic column (on the left) and magnetostratigraphic data by thermal demagnetization (on the right) for Labuerda and Forcaz sections (localization Fig. 4). In the Labuerda section, samples above $300 \mathrm{~m}$ are neatly aligned and separated in two different polarity zones. In the segment between $\sim 100$ and $300 \mathrm{~m}$, it remains difficult to interpret the paleomagnetic signal unambiguously possibly due to the presence of minor splays from the main thrust mapped by Pickering and Bayliss (2009). In the Forcaz section, only the uppermost before-last sample indicates a normal polarity and it is thus represented as a grey level in the R1 chron. Abbreviations: B: Banaston SGF; A: Ainsa SGF; MTC: mass transport complexes. $\sim 60 \mathrm{~cm}$ thick) and follows a large interval of slumped deposits and downlapping strata (Fig. 5C). Second, at $825 \mathrm{~m}$, the so-called Castellazo level was interpreted by Dreyer et al. (1999) as carbonate breccia with meter-scale olistolithic blocks of bioconstructed carbonates collapsed from fringing limestone formations. More recently, these features were identified as dolomitic concretion by Hoareau et al. (2009, 2015; Fig. 5D). Similar concretions are observed around $620 \mathrm{~m}$ (Fig. 7). Third, the so-called San Lino level is a thick (about $1 \mathrm{~m}$ ), regional level of dark mudstones (Fig. 5E) identified in Dreyer et al. (1999), and interpreted as a marker of a basin-wide episode of anoxia by Mochales et al. (2012a). It also corresponds to a dark shale horizon and sample MFS-4 in Scotchman et al. (2015a). This level is considered the base of the overlying Sobrarbe deltaic complex (Arbués et al., 2011). Finally, the Morillo de Tou section is characterized by a nummulitic bed at $100 \mathrm{~m}$ (Fig. 7) and few dark mudstone levels around $440 \mathrm{~m}$ and $970 \mathrm{~m}$ (Fig. 7).

\subsection{Magnetostratigraphy and biostratigraphy}

The marlstones of the Ainsa basin show a viscous component below $280^{\circ} \mathrm{C}$. Above this temperature, a Characteristic Remanent Magnetization (ChRM) component is isolated for a majority of the samples. The maximum unblocking temperature of the ChRM is observable from $400^{\circ}$ to $450{ }^{\circ} \mathrm{C}$ in stable samples (See Supplementary material I, Fig.S.2.1). This range of temperature suggests that iron oxides such as magnetite are the main magnetic carriers. Previous paleomagnetic studies (Muñoz et al., 2013; Mochales et al., 2012b) highlighted a rotation of the Ainsa basin clockwise up to $60^{\circ}$. A north-east direction with downwards inclinations is thus expected for normal polarity samples, and south-west direction with upwards inclinations is expected for reverse polarity samples (See Supplementary material I, Fig.S.2.1). The significant clockwise rotation recorded by normal and reversed polarity ChRM components makes 


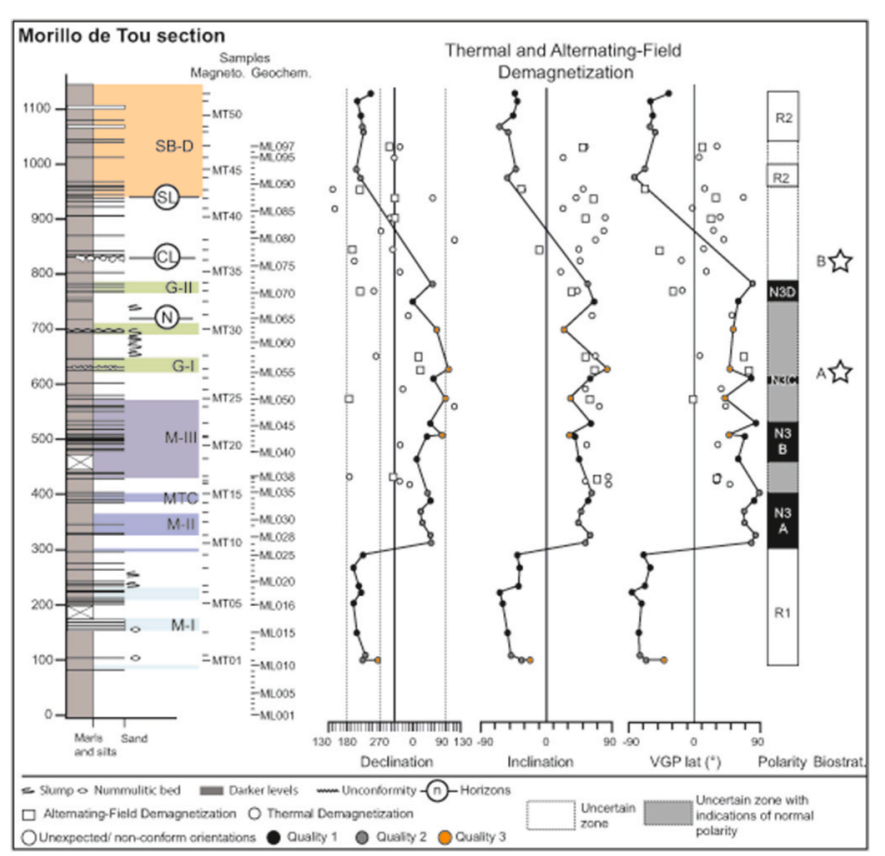

Fig. 7. Stratigraphic column (left) and magnetostratigraphic data (thermal demagnetization and Alternating-field demagnetization) for the Morillo de Tou section (location Fig. 8). Note the clear reversal from reverse (R1) to normal (N3A) polarity at ca. $300 \mathrm{~m}$ followed by a large number of unclear and low-quality data from $400 \mathrm{~m}$ to $976 \mathrm{~m}$. Samples indicate reverse polarity for the top of the section. From N3A to N3D, despite ambiguous declination, inclination is always positive suggesting normal polarity. Note the low quality of the alternating field data and ambiguous orientations and the position of two biostratigraphic sites (stars A and B). Abbreviations: SL: San Lino level; CL: Castellazo level; N: Negative oxygen excursion level; MTC: Mass transport complexes; N: normal polarity; R: reverse polarity; M: Morillo SGF; G: Guaso SGF; SB-D: Sobrarbe deltaic complex.

them easily distinguishable from north-directed recent overprints. Samples showing unexpected orientations are indicated in white in Figs. 6 and 7 and were not considered to define normal/reverse polarity magnetozones in the local magnetostratigraphy. For sites where multiple samples were measured, the specimen showing the best quality was selected for VGP (Virtual Geomagnetic Pole) calculation. Samples with magnetic moment non-conform to the expected Eocene magnetic paleofield represent approximatively $45 \%$ of the results. They are distributed on all the three sections with a cluster between LB009 and LB035 at the base of Labuerda section and one at the top of Morillo de Tou section (MT35 to MT43 samples). Several causes may account for samples showing flawed directions. At the base of the Labuerda section, the cluster of flawed directions could be explained by slumps or tectonic deformations associated with minor splays from the neighboring thrust. The second cluster of flawed directions is again associated with a large interval characterized by slumps (650-700 $\mathrm{m}$ in the Morillo section). The application of an external high field generated, for instance, by a lightning strike, can produce magnetic moment with intensity orders of magnitude higher than regular samples overprinting the signal (LB013-LB014). Finally, samples close to reversal boundaries can also show unusual directions due to either the distinct non-dipolar behavior of the Earth's magnetic field during transitions and/or the delayed locking and overprint of both normal and reverse components upon burial (e.g., LB058 to LB061, Fig. 6). Few samples also punctually showing unexplained and unexpected directions were rejected (LB017-1B, LB024-1B, LB033-1C, LB035-2A and B, LB037-1B, LB054-1B, LB055-1A, LB057-1B, LB059-1B, LB085.2A, LB109-2A and FR20-2A). In total, 35 samples of quality one, 39 samples of quality two, and 5 samples of quality three give a reliable record of the different magnetozones occurring in the basin.

The Labuerda magnetic section begins with a clear normal polarity zone (N1, LB003-LB008, Fig. 6) followed, from LB009 to LB035, by a cluster of noisy data. From LB035 to LB059, normal polarity is again measured (N2, Fig. 6). At LB060 (528 m, Fig. 6), a clear reversal from normal polarity zone (N2) to reverse polarity zone (R1) occurs. From LB060 (528 m) to FR040, almost all samples indicate reverse polarity (R1, Fig. 6). As Forcaz and Labuerda sections are overlapping, the reversal magnetozone identified in both sections corresponds to R1 (Fig. 6).

The quality of magnetostratigraphic samples for the Morillo de Tou section (MT, Fig. 7) is lower than for the Labuerda and Forcaz sections. Clear magnetozones can still be identified, but the larger proportion of noisy samples lead to uncertainties in the exact position of the magnetic polarity reversals. The magnetostratigraphic dataset begins $100 \mathrm{~m}$ above the geochemical dataset of the Morillo de Tou section (ML section) with a clear reverse interval (MT01-MT09, R1, Fig. 7). At MT10 (313 m), a polarity reversal is recorded. The following normal polarity (MT10MT33, Fig. 7) is subdivided into three normal polarity zones N3A, N3B, and $\mathrm{N} 3 \mathrm{C}$ due to the unexpected declinations measured in the samples (Fig. 7). Despite these unexpected declinations, inclinations remain positive, indicating a normal polarity magnetozone. From MT35 to MT47, measured samples show mixed declinations and inclinations. From MT48 to MT52, a clear reverse polarity is recorded (R2, Fig. 7). The geographical localization of the samples as well as their polarity (normal, reverse and unclear) are reported in Fig. 8.

The alternating-field method (AF, squared dots Fig. 7) was additionally performed on ten samples of the Morillo de Tou section. The samples provide low quality results (50\% of quality 3 samples) with numerous unexpected orientations among quality 1 and 2 samples. Due to the low resolution between samples and the low quality of the data, AF results were not used further in this study.

Fisher means were calculated for all reliable reverse and normal samples (See Supplementary material I, Fig.S.2.2). After tilt correction, a mean declination/inclination of $44.4^{\circ} / 53.4^{\circ}$ for the normal polarity and $221.3^{\circ} /-39.7^{\circ}$ for the reverse polarity intervals were obtained from all the reliable samples. Those results are consistent with the measured clockwise rotation of the basin (Muñoz et al., 2013). Finally, paleomagnetic means in stratigraphic (tilt corrected) coordinates are better clustered than in geographic coordinates which support a pre-folding ChRM acquisition (See Supplementary material I, Fig.S.2.2).

The two analyzed biostratigraphic sites, (sample A: ML055 and B: ML075) are indicated in Fig. 7. Sample (A) bears the following nannofossils: C. expansus, S. furcatolithoides, S. spiniger, R. hillae, R. umbilicus, S. runus, D. wemmelensis, C. vanheckiae, S. obtusus, S. richteri, D. filewiczii, and $D$. stavensis. They are ascribed to lowermost NP16 zone (EoceneLutetian). In sample (B) the nannofossils D. bifax, S. furcatolithoides, S. spiniger, C. vanheckiae, C. solitus, $R$. umbilicus, $S$. runus, and $S$. richteri indicate early NP16 zone (Eocene-Lutetian). For the detailed nannofossils micropaleontology, refer to the Supplementary material I, S.3.

\subsection{Geochemistry}

\subsubsection{Stable isotopes}

4.3.1.1. Oxygen isotopes. Oxygen isotope data vary between -6 and $-4 \%$ in the studied succession (Fig. 9). The $\delta^{18} \mathrm{O}$ values show a general increase in Labuerda and Forcaz sections (LB001 to FR047, Fig. 9) interrupted by a decrease of approximately $1 \%$ at the base of the Morillo de Tou section (ML001 to ML010, Fig. 9). This decrease is followed by $\delta^{18} \mathrm{O}$ values around $-5 \%$ until $720.5 \mathrm{~m}$ in the Morillo de Tou section where a negative excursion occurs (-6.97 $\pm 0.07 \% \delta^{18} \mathrm{O}$, ML065, N-level, Fig. 9). After this negative oxygen isotope excursion ( $\mathrm{N}$-level), $\delta^{18} \mathrm{O}$ values become progressively more positive, returning to pre-excursion values. 


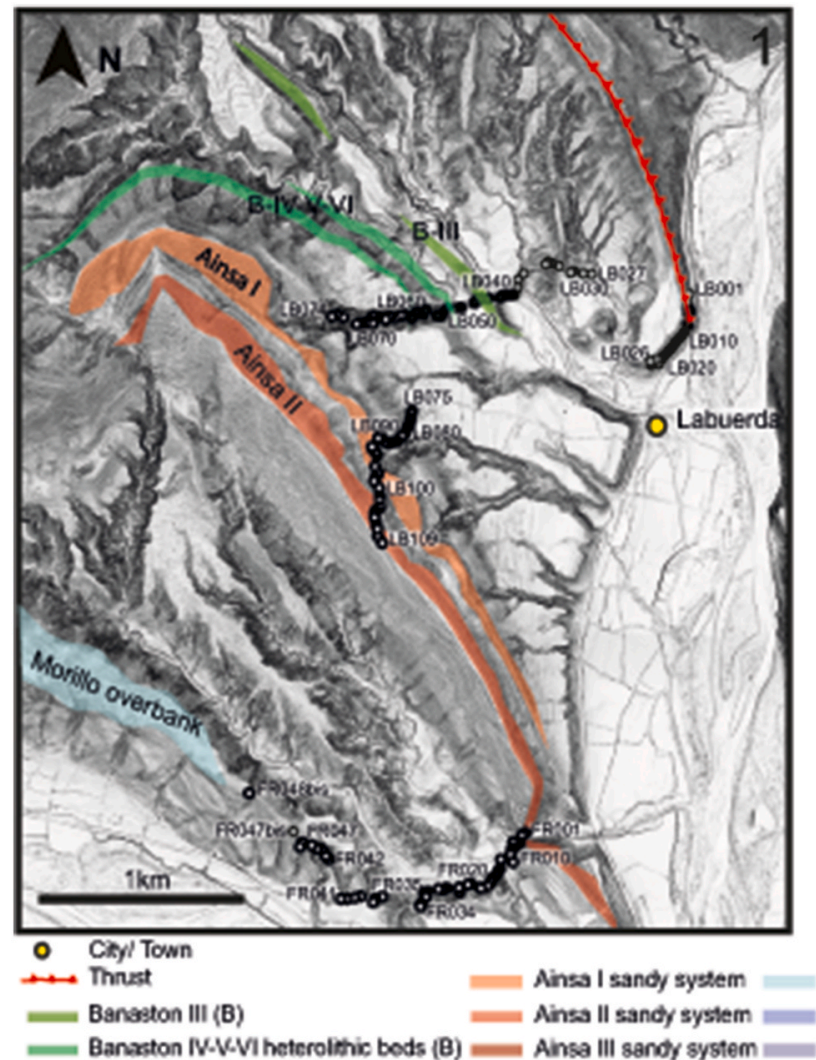

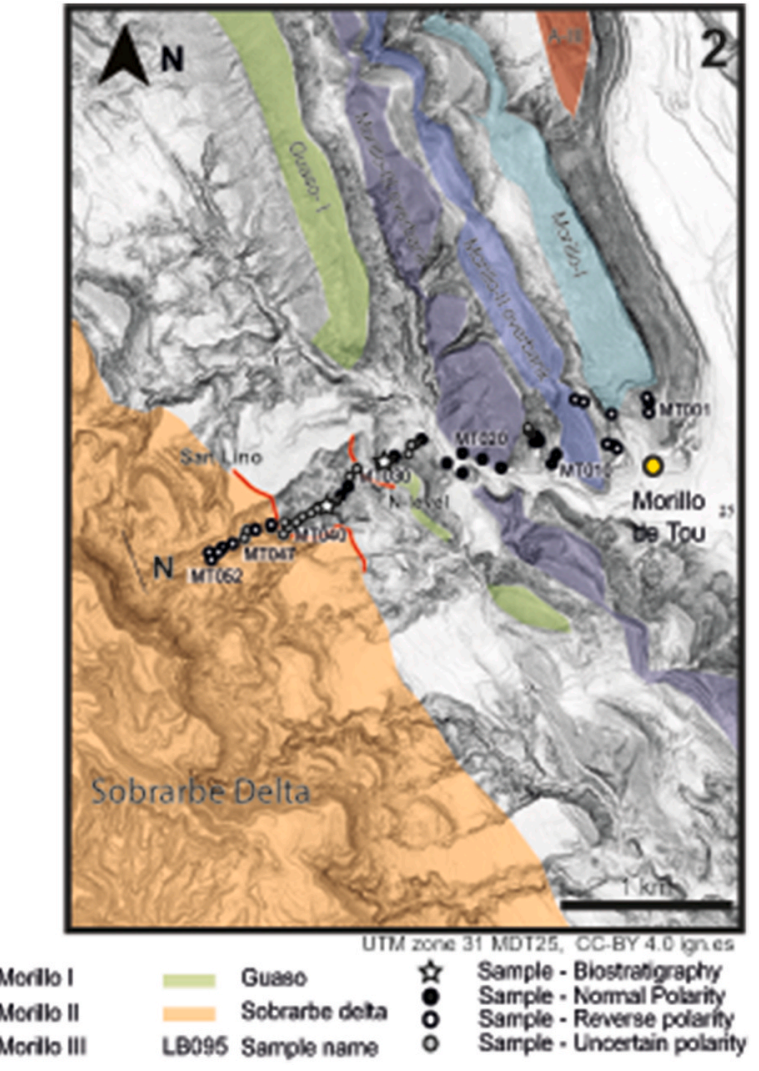

Fig. 8. Detailed magnetostratigraphic sections on high-resolution (LIDAR) digital elevation models (Fig. 4 for area 1 and 2 localizations). Sandy packages of sediment gravity flow systems are indicated in color based on the geological map of Pickering and Bayliss (2009). Black dots indicate a normal polarity zone, white dots indicate reverse polarity. The position of the San Lino level interval as indicated in Mochales et al. (2012a) and the negative oxygen excursion (N-level, section 4.3.1.1) are also indicated. (Digital elevation model from the Centro nacional de Informacion Geografica, PNOA, 264-4706; https://centrodedescargas.cnig.es, MDT25 2015 CC-BY 4.0 ign.es). (For interpretation of the references to color in this figure legend, the reader is referred to the Web version of this article.)

4.3.1.2. Carbon isotopes. The $\delta^{13} \mathrm{C}$ records show large-scale positive and negative shifts in all sections (Fig. 9). At the base of the studied section, the Gerbe system is characterized by negative values showing smallscale variations of the $\delta^{13} \mathrm{C}$ around $-1.5 \%$ (see Gerbe in Fig. 9), which is consistent with data in Castelltort et al. (2017). Banaston SGF system is marked by a positive excursion of the $\delta^{13} \mathrm{C}$ values (from $-0.8 \%$ to $0.4 \%$ o in B-II? member, Fig. 9) also noticed by Castelltort et al. (2017). More negative $\delta^{13} \mathrm{C}$ values were measured on the succession covering the Banaston off-axis deposits (B-III-IV-V-VI) and Ainsa (I-II) SGF systems (Fig. 9). Above the Ainsa II sandy deposits (A-II in Fig. 9), a progressive shift to higher $\delta^{13} \mathrm{C}$ values is measured.

From Forcaz to Morillo de Tou sections, the $\delta^{13} \mathrm{C}$ profiles show more positive values with small-scale variations between -1 and $0 \%$ near Morillo I sandbodies and Guaso II SGF packages (Fig. 9).

\subsubsection{Organic matter analysis}

The total organic carbon content (TOC in wt.\%) is generally low in the marlstones of the Ainsa basin ( $0.26 \mathrm{wt} \%$ on average; Fig. 9). Two distinct trends can be noted in the studied succession. From Gerbe to Ainsa II, TOC concentrations are averaging around $0.24 \mathrm{wt} \%$ (LB001 to FR027, Fig. 9), while from Ainsa-II (FR028) to the Sobrarbe deltaic complex (ML096), TOC concentrations average $0.32 \mathrm{wt} \%$. This general pattern is punctuated by few discrete increases in the TOC concentrations in the Gerbe SGF package (Gerbe, Fig. 9), the Ainsa II SGF package (TOC values up to $0.49 \mathrm{wt} \%$, A-II, Fig. 9) and in the Forcaz section (FR030 to FR047, Fig. 9).

The few darker levels identified in the basin are not correlated with a substantial increase in the TOC (e.g., San Lino level in the Morillo de Tou section, SL, Fig. 9), except for a darker marlstone interval in the Guaso SGF system (N-level in the Morillo de Tou section, 720.5 m, Fig. 9). This darker level is characterized by a significant increase in the TOC (up to $0.70 \mathrm{wt} \%)$ and a negative excursion of the $\delta^{18} \mathrm{O}$ values $(-6.97 \pm 0.07 \%$, Fig. 9).

The ratio of HI (hydrogen index) versus OI (oxygen index) and HI versus $\mathrm{T}_{\max }$ (the temperature at the maximum rate of hydrocarbon generation), for TOC higher than $0.2 \mathrm{wt} \%$, inform about the type of kerogen (II-III or IV) found in the basin and the different sources of organic matter (McCarthy et al., 2011, Fig. 10). Type II kerogen is sourced from plankton and algae in marine settings, type III kerogen has an important contribution of terrestrial plant-derived organic matter deposited in marine environments and type IV kerogen corresponds to eroded, reworked, or biologically oxidized organic matter (McCarthy et al., 2011). For the upper Hecho Group, HI-OI and HI-T $\max$ plots suggest that the organic matter is principally type III kerogen with few samples within the fields of type II and IV kerogens (Figs. 9 and 10). The predominant continental input of organic matter in the Ainsa basin is punctually replaced by marine organic matter (kerogen II) and reworked, oxidized, and eroded organic matter (kerogen IV). An increase in $\mathrm{HI}$ can be noted in the Forcaz section coupled with the occurrence of type II kerogen (Fig. 9 and FR samples in Fig. 10B). Most type IV kerogen samples are clustering at the base of the studied section (see Gerbe, B-II? And B-III members in Fig. 9). During Guaso SGF systems deposition, a decrease in HI values indicates a pronounced input of terrestrial organic matter coeval with the negative $\delta^{18} \mathrm{O}$ excursion.

Finally, the general increase of $\mathrm{T}_{\max }$ with depth and the general shift from immature to overmature organic matter in the basin with increasing depth (LB, FR, and ML clusters in Fig. 10B) reflects the increasing thermal maturation with burial (Fig. 9). 

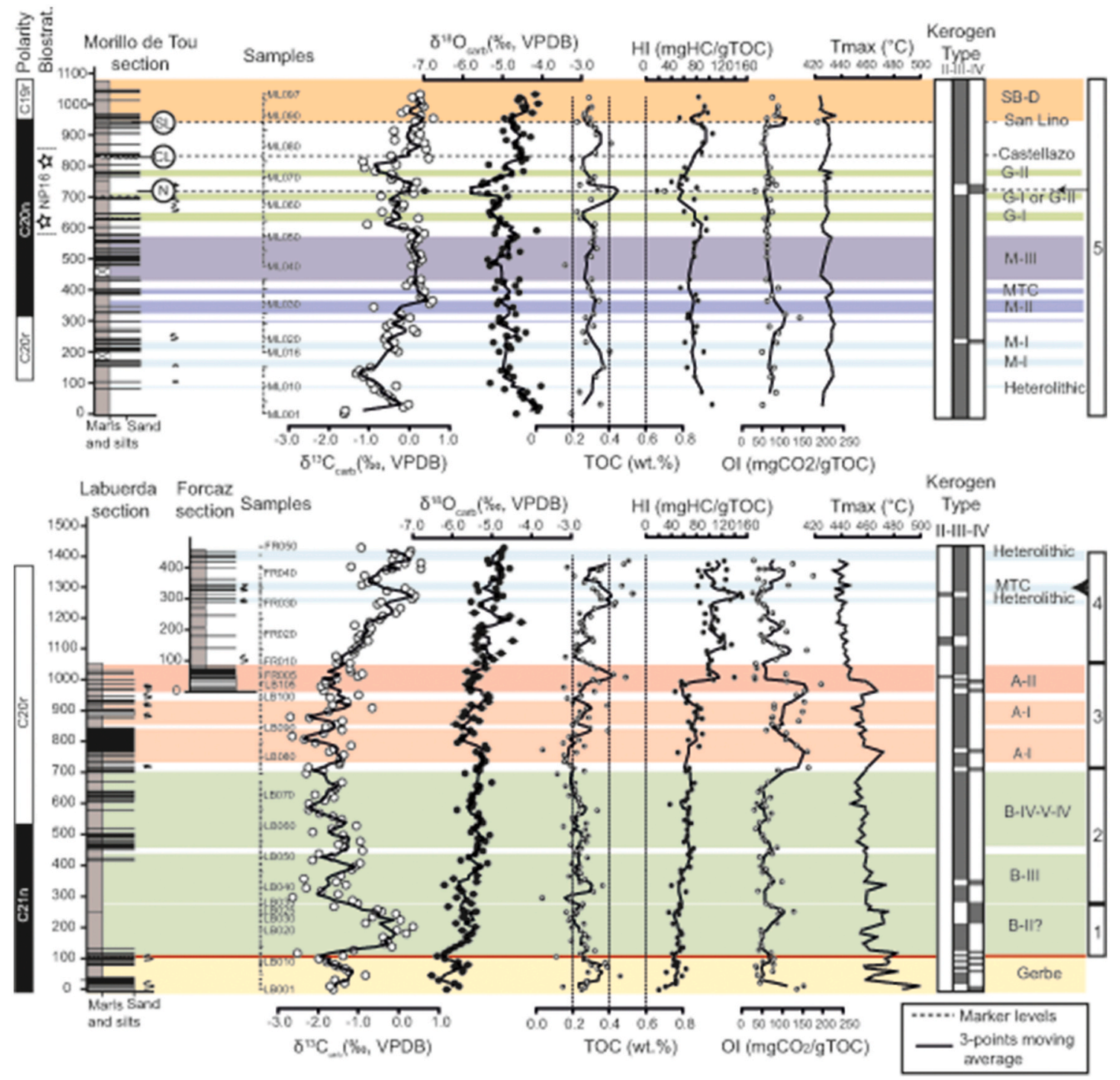

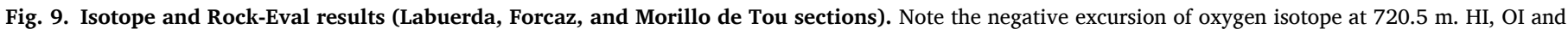

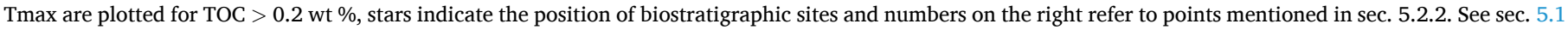

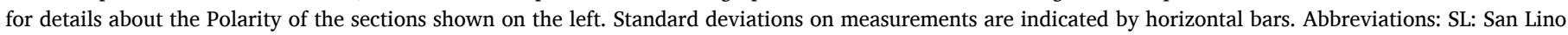

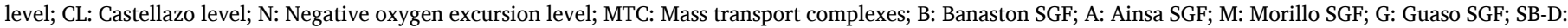
Sobrarbe deltaic complex.

\subsubsection{Mineralogy, major elements and trace elements}

Detailed X-ray fluorescence and X-ray diffraction data for Labuerda and Forcaz sections can be found in Fig. 14 and in the Supplementary Material I, S.4. This dataset, acquired at low resolution, allows the identification of the main sequences of fining and coarsening upward and supports the main stratigraphic interpretation (See Supplementary Material I, S.4). This dataset was additionally used to evaluate the imprint of diagenesis on the marlstones (See sec. 5.3.1 Effects of diagenesis).

\subsubsection{Ainsa stack}

The data in Castelltort et al. (2017) and this study generate a stable isotope and Rock-Eval dataset for the complete Hecho Group in the Ainsa basin (Fig. 11). Correlation between the Pueyo off-axis section (Castelltort et al., 2017, Fig. 11) and the Labuerda section (this study) was assessed with a geological map and supported by lateral correlation of isotopic records (LB021=GB33, in B-II?, Fig. 11). In this work, Banaston I was placed in the turbidite stack previously identified as Gerbe II by Castelltort et al. (2017). Our interpretation follows the map of Cornard and Pickering (2019) and sets the correlation between both sections in the lateral equivalents of Banaston I (Fig. 11).

A geochemical dataset (carbon and oxygen stable isotopes, TOC, HI, OI and $\mathrm{T}_{\max }$ ) of $3767 \mathrm{~m}$ (stratigraphic thickness) covers the entire Hecho Group (from Arro SGF system to the distal deposits of the Sobrarbe deltaic complex, Fig. 11). High amplitude shifts of $\delta^{13} \mathrm{C}$ ratio $(1-2 \%$ ) can be noted throughout the Hecho Group, with generally high values in Morillo and Guaso SGF systems and the distal deposits of the Sobrarbe deltaic complex (Fig. 11). The $\delta^{18} \mathrm{O}$ values show a gradual increase toward the top of the basin, interrupted by a negative excursion at $3455 \mathrm{~m}$ (ML065, Morillo de Tou section, N-level; Figs. 9 and 11). The marlstones of the Ainsa basin have a TOC close to $0.3 \mathrm{wt} \%$ except for a clear interval enriched at the base of Pueyo off-axis section (Fig. 11, blue rectangle in the Pueyo off-axis section). In Fig. 11, the positive TOC excursion observed during the $\mathrm{N}-$ level (N-level, see sec. 4.3.2 Organic matter analysis, Fig. 9) is buffered by the 5-points moving average. High Hi values can be observed in the marlstone interval succeeding Ainsa SGF sandy packages (red rectangle, Fig. 11) suggesting major pulses of marine organic matter. 

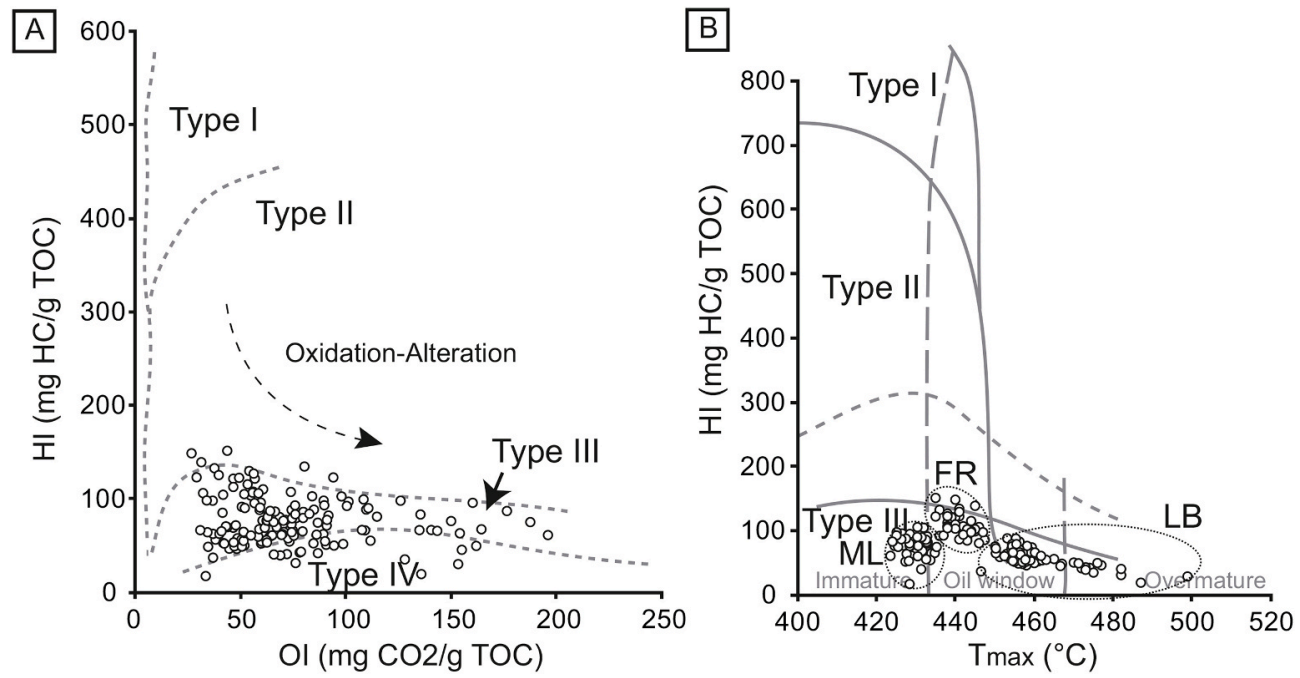

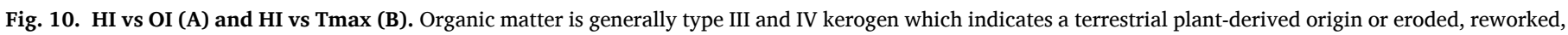
or biologically oxidized organic matter (McCarthy et al., 2011). Abbreviations: LB: Labuerda section; FR: Forcaz section; ML: Morillo de Tou section.

\section{Discussion}

\subsection{Tectonic and climatic control on the deep marine sedimentation of the Hecho Group}

During the deposition of the Hecho Group, the tectonic activity is characterized by a pulse of exhumation in the Axial Zone, followed by the subsequent activation of thrust systems, the growth of anticlines, and a progressive clockwise rotation transforming the Ainsa basin in a piggyback basin (see sec. 2 Geological setting for details). Several authors studying the cyclicity of sediments gravity flow deposits and the timing of deposition concluded that local tectonic controls the large-scale geometries of the deposits (e.g., Pickering and Bayliss, 2009; Scotchman et al., 2015a; Castelltort et al., 2017; Clark et al., 2017; Cantalejo et al., 2020b; Vinyoles et al., 2021).

In more detail, a pulse of exhumation rates (Whitchurch et al., 2011) and thrusts propagation were associated with the deposition of Fosado ( Chanvry et al., 2018) and Arro SGF systems (Castelltort et al., 2017). The activation of the La Fueba thrust system during the late Ypresian was associated with the deformation of the lower Hecho Group (Muñoz et al. 2013). During C21n chron, the emplacement of the Gavarnie thrust sheet modified the depozone boundaries in the basin (Vinyoles et al., 2021). In addition, a significant rate of relief growth in the Axial Zone, and the emplacement of the Montsec thrust sheet were linked to Gerbe I and II members (Mutti et al., 1985; Muñoz et al., 2013; Arbués et al., 2011; Scotchman et al., 2015a). Finally, associated with the emplacement of the Gavarnie thrust sheet, the development of the Sobrarbe fold system took place during the early Lutetian with the progressive growth of anticlines (Mediano anticline growth: early Lutetian - Bartonian; Poblet et al., 1998; Boltaña anticline growth: middle Lutetian-Priabonian; Muñoz et al., 2013).

While these phases in the deformation of the Ainsa basin explain the large-scale trends observed in the sediments, a more precise correlation between tectonic and the deposition of each SGF system remains challenging. Although such relation cannot be excluded, we propose that the presence of salt layers at the base of thrusts units (Muñoz et al., 2013) would generate predominantly ductile deformation unlikely to produce the pulses observed at multimillennial scale in the sedimentary succession.

Alternatively, studies suggested that cyclic stratigraphy at the multimillennial scale may rather be controlled by climatic modulations (Pickering and Bayliss, 2009). Cantalejo and Pickering $(2014,2015)$ and Cantalejo et al. (2020b) recognized Milankovitch type cyclicities with elemental and isotope records of several sections of the Ainsa basin. Cantalejo and Pickering (2014) suggested control of Milankovitch driven climatic cycle on sediment export through a change in humidity or small scale eustatic variations directly related to climate. The geochemical dataset of Schotchman et al. (2015b) in the Guaso system also highlighted a dominant orbital component in the frequency of terrigenous input in the Ainsa basin. More recently, however, Castelltort et al. (2017) showed that $\delta^{13} \mathrm{C}$ variations in the lower systems of the succession (Fosado to the lower Banaston systems) tied to the eustatic curve of Miller et al. (2005) seem to indicate a dominant, but not exclusive, eustatic control on the occurrence of SGF packages in the basin. Additionally, Cantalejo et al. (2020b) proposed climate coupled with eustatism as the main drivers of delivery of sand to deep marine settings. The precise role of eustatism thus remains to be discussed and a robust chronostratigraphy of the successions is crucial to decipher the possible drivers behind such sedimentary signals. Previous age constraints in the Ainsa basin are provided by the magnetostratigraphic studies of Holl and Anastasio (1993), Bentham and Burbank (1996), Mochales et al., 2012a and Cantalejo et al. (2020a), the biostratigraphic data of Jones et al. (2005), Pickering and Corregidor (2005) and Scotchman et al. (2015a), as well as by the carbon isotope stratigraphy of Castelltort et al. (2017). In this paper, our high-resolution magnetostratigraphic dataset provides material to build a precise age model from Banaston SGF system to the Sobrarbe deltaic complex.

\subsection{New age model for the upper Hecho Group}

The age model developed in this study is based on a new magnetostratigraphic dataset integrated into the frame of earlier magnetostratigraphic studies of Mochales et al. (2012a), Bentham and Burbank (1996), and Cantalejo et al. (2020a). This age model is strengthened by existing and new biostratigraphic data. Correlations with existing studies are based on the lateral and vertical continuity of the sedimentary series observed in the Ainsa basin. These correlations suggest the absence of significant hiatuses, unconformities, and preservation of all magnetozones.

The total composite magnetostratigraphic section consists of five long magnetozones (Figs. 6, 7, and 12) correlated to the existing stratigraphic divisions of the Ainsa basin by regional marker levels. The section begins with the normal polarity N1 in the Gerbe system, followed by a normal polarity for the lower systems of Banaston (N2, Fig. 12). A shift to reverse polarity (R1) is observed up to Morillo SFG system where polarity shifts back to normal (N3A, B, C, and D, Fig. 12). The distal 


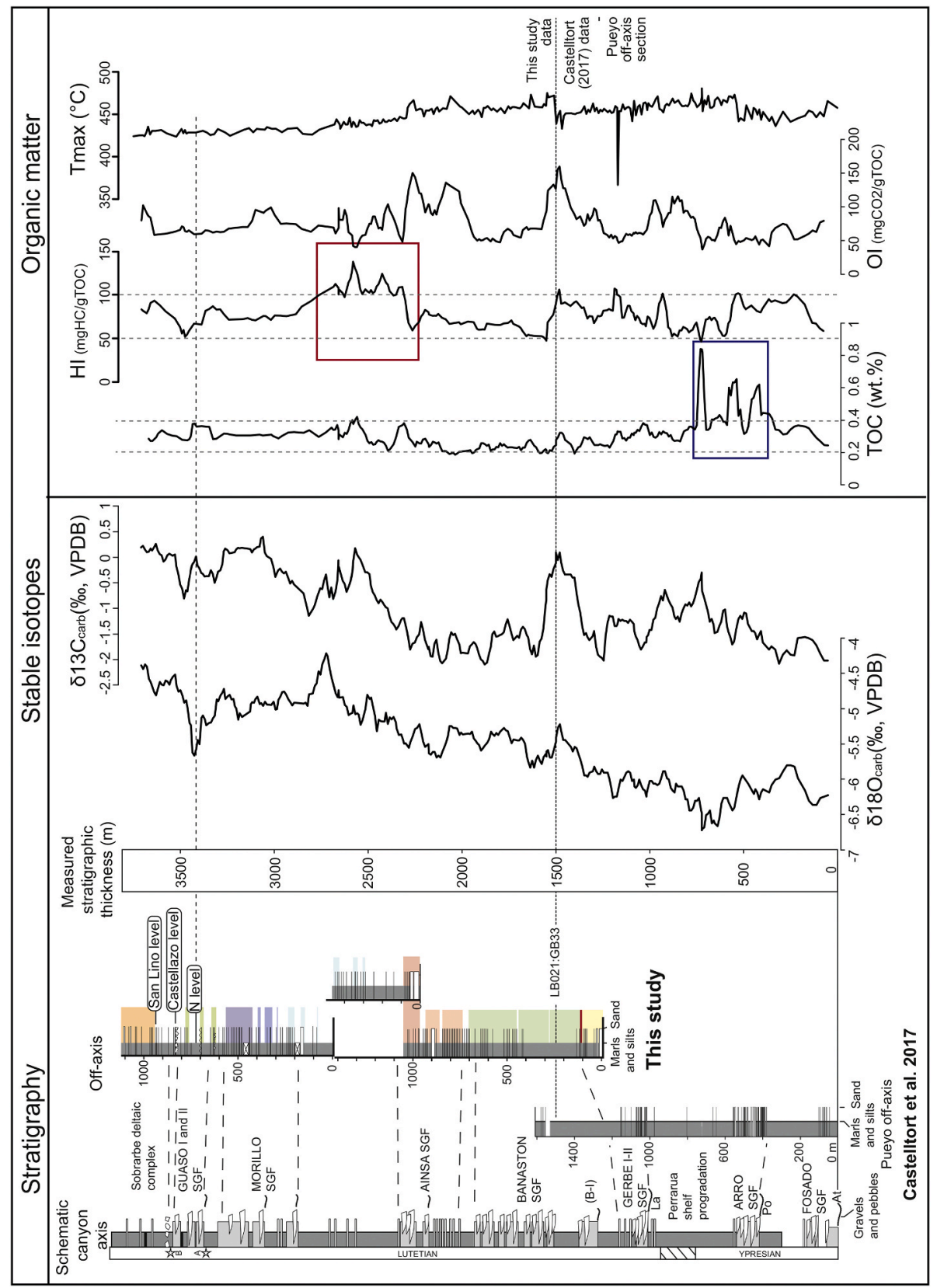

Fig. 11. Compilation of data from Castelltort et al., 2017 and this study with 5-points moving average isotope, total organic content, hydrogen index, oxygen index curves and Tmax $\left({ }^{\circ} \mathrm{C}\right.$; raw data). The two new biostratigraphic samples (A and B) are indicated by stars in the Schematic canyon axis column. The $\delta^{18} \mathrm{O}$ profile show a clear negative excursion at $\mathrm{N}$-level in the Guaso system.

deposits of the Sobrarbe deltaic complex are characterized by a reverse polarity (R2, Fig. 12). The correlation with Mochales et al. (2012a) was done by identification of the San Lino regional marker level in N3 (Figs. 5, 7, 9, and 13). In Mochales et al. (2012a), this dark level is located $20 \mathrm{~m}$ below the C20n to C19r boundary (ca. 42.4 Ma recalibrated to GPTS 2012), which suggests that N3 corresponds to C20n and $\mathrm{R} 2$ to $\mathrm{C} 19 \mathrm{r}$. Interpretation of N3A, B, C, and D as belonging to the same normal interval is consistent with the data of Mochales et al. (2012a) that identified a long normal polarity zone below the San Lino level (Coscollar section, Fig. 13). This interpretation is also in concordance with the C20n chron identified below the Sobrarbe delta by Bentham and Burbank (1996) (Mediano section, Fig. 13) and is coherent with the identification of NP16 nannoplankton zone in two new biostratigraphic sites in the Guaso SGF system (ML065 (A) and ML075 (B) in Fig. 12). The exact position of the reversal between $\mathrm{C} 20$ and $\mathrm{C} 19$ chrons is questionable in our section due to the scarcity of good quality data in this stratigraphic interval. However, it was placed $20 \mathrm{~m}$ above the San Lino level in accordance with Mochales et al. (2012a) dataset. In Mochales et al. (2012a) the identification of C19r was confirmed by two biostratigraphic data (GO and EO) indicating SBZ15 in the Coscollar section (Fig. 13).

Considering continuous sedimentary series, R1 is interpreted as C20r and N1 and N2 as C21n. The identification of C21n in the Banaston SGF system is supported by the presence of large benthic foraminifera and nannoplanktons characteristic of SBZ13 and NP14, respectively (Scotchman et al., 2015a). The N1 normal zone is identified as belonging to the C21n chron following the Castelltort et al. (2017) age model. This large-scale interpretation is consistent with Cantalejo et al. (2020a) age model based on magnetostratigraphy acquired in different sections in the basin. Both models have however the following differences 


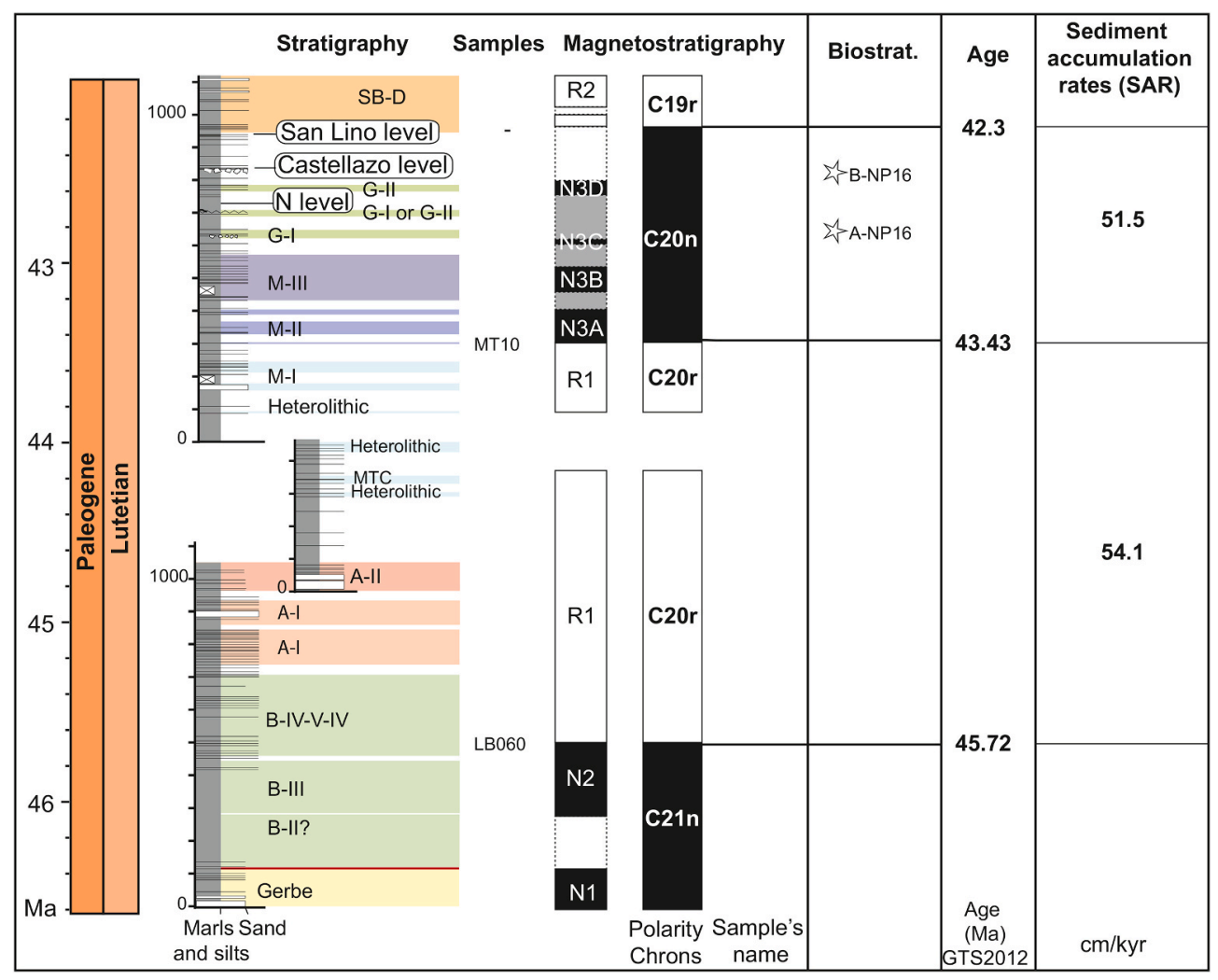

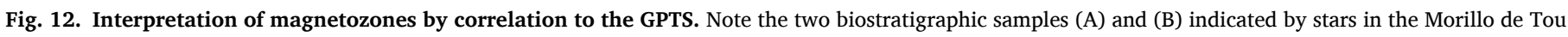

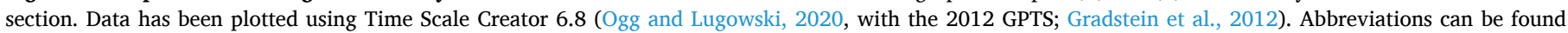
in Fig. 9.

regarding the position of the two reversals found in the succession of the upper Hecho Group. First, Cantalejo et al. (2020a) place the transition from C21n to C20r between Banaston V and IV. Secondly, in this study, the transition from $\mathrm{C} 20 \mathrm{r}$ to $\mathrm{C} 20 \mathrm{n}$ is recorded below the second member of Morillo (M-II) while Cantalejo et al. (2020a) placed it in M-III member. As shown in Fig. 13, the sedimentary successions are condensed near the Boltaña anticline (Coscollar section of Mochales et al., 2012a) and on the eastern flank of the Mediano anticline (Bentham and Burbank, 1996; Fig. 13).

According to this age model, the Hecho Group was deposited between 50.5-50.2 Ma (Castelltort et al., 2017) and 42.3 Ma (this study). More precisely, the marlstones above Banaston III-IV SGF systems are dated at 45.72 Ma and the base of Morillo II at 43.43 Ma (GTS, 2012; Gradstein et al., 2012, Fig. 12). Thus, rough sediment accumulation rates are estimated at (1) $54.1 \mathrm{~cm} / \mathrm{kyr}$ between Banaston IV and Morillo II SGF systems, (2) $51.5 \mathrm{~cm} / \mathrm{kyr}$ between Morillo II SGF deposits and the San Lino level (Fig. 12).

\subsection{Isotope records}

\subsubsection{Effects of diagenesis}

One of the main sources of uncertainty in the interpretation of carbonate stable isotopes comes from the potential diagenetic alteration of the primary signals. During burial, the $\delta^{13} \mathrm{C}$ and $\delta^{18} \mathrm{O}$ values of marine carbonates are often shifted toward more negative values (e.g., Brand and Veizer, 1981; Marshall, 1992). Changes in pore water compositions and a temperature increase can lead to recrystallization and neomorphism and a shift of $\delta^{13} \mathrm{C}$ and $\delta^{18} \mathrm{O}$ values to lower values (Marshall, 1992; Knauth and Kennedy, 2009, Fig. 14C). In such cases, a $\delta^{13} \mathrm{C}$ vs. $\delta^{18} \mathrm{O}$ covariation is often observed (Brand and Veizer, 1981; Knauth and Kennedy, 2009). During burial diagenesis, the isotopic composition of formation fluids and the higher water/rock ratio of oxygen, compared to carbon, tend to shift the $\delta^{18} \mathrm{O}$ to lower values while $\delta^{13} \mathrm{C}$ shows minor changes (see alteration arrow in Fig. 14C; Knauth and Kennedy, 2009). In the marlstones of the Hecho Group, $\delta^{13} \mathrm{C}$ and $\delta^{18} \mathrm{O}$ values are generally lower than their global marine equivalents (Eocene benthic marine foraminifera records of Cramer et al., 2009) and plot on the left border of the lithification domain as defined by Knauth and Kennedy (2009) (Fig. 14C). This shift, combined with meteoric water temperature estimated at $150^{\circ} \mathrm{C}$ from calcite veins in the Hecho Group (Mansurbeg et al., 2009), suggests some diagenetic overprint on the studied deposits. In addition, Hoareau et al. (2015) showed several pieces of evidence for phases of diagenesis, based on facies and geochemical evaluation of dolomite concretions, foraminifera and host-marlstones in the vicinity of concretions in the Sobrarbe deltaic complex. Therefore, the primary $\delta^{13} \mathrm{C}$ and $\delta^{18} \mathrm{O}$ values were probably modified by post-depositional processes (i.e., meteoric diagenesis, fluid-rock interaction, temperature changes, isotopic resetting). However, the following points suggest that diagenesis did not affect significantly our dataset.

(1) Absence of the characteristic inverted-J covariation trend of $\delta^{13} \mathrm{C}$ $\delta^{18} \mathrm{O}$ linked to meteoric diagenesis, the moderate $\delta^{13} \mathrm{C}$ vs. $\delta^{18} \mathrm{O}$ covariance (Pearson correlation $\mathrm{r}=0.53$, $\mathrm{p}$-value $<0.001$ ), and the lack of field evidence of subaerial exposure point to the absence of significant meteoric influence on the studied successions.

(2) The $\delta^{13} \mathrm{C}-\delta^{18} \mathrm{O}$ cross-plots are often used to assess lithification and alteration of marine carbonate deposits (e.g., Brand and Veizer, 1981; Heydari et al., 2001; Schobben et al., 2016; Knauth and Kennedy, 2009) and can be used to compare different endmembers of the system. In the Hecho Group, a petrographic evaluation of the marlstones in the slope deposits of the Sobrarbe deltaic complex by Hoareau et al. (2009) suggests that marlstones are composed of approximately $50 \%$ of micritic magnesian calcite 


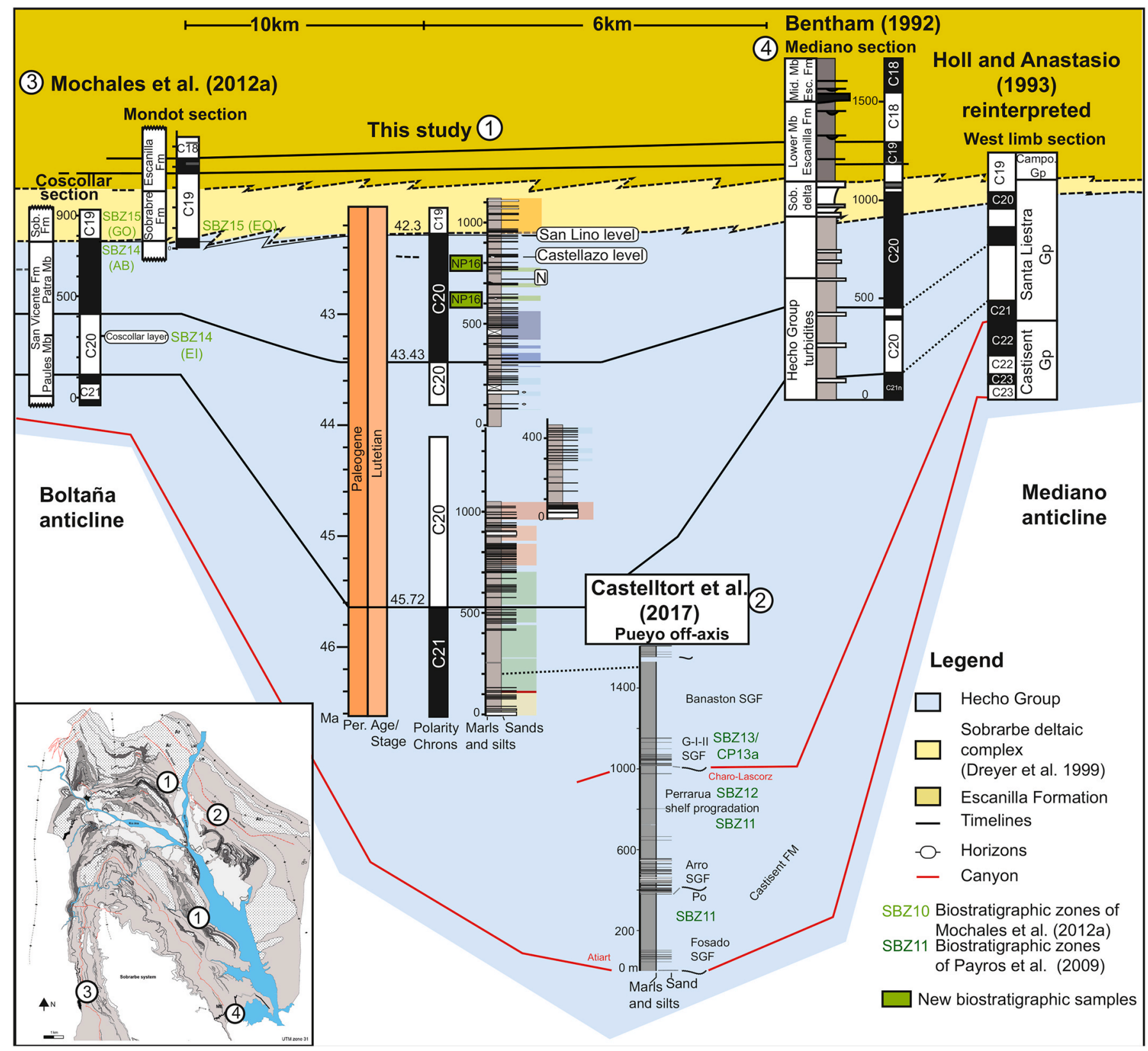

Fig. 13. Principal correlations with the stratigraphic sections of Bentham (1992), Holl and Anastasio (1993), Mochales et al. (2012a) and Castelltort et al. (2017). Vertical thicknesses are respected. Note the important changes in stratigraphic thickness between this study and (Mochales et al., 2012a) sections and the high preservation of the deep marine series in the Ainsa basin. Abbreviations can be found in Fig. 9.

and $50 \%$ of detrital grains. The detrital fraction is composed predominantly of clays and to a lesser amount of quartz, small-rounded dolomite and calcite $(<5 \%$ in the studied samples of Hoareau et al., 2009), K-feldspar and minor diagenetic dolomite rhombs and calcite (Hoareau et al., 2009, 2015). Rare foraminifera are also found in the marlstones (Hoareau et al., 2009, 2015). Most of the isotope signal is thus controlled by precipitation of micritic cements during lithification as highlighted by the cluster of the carbonate mudstones on the left border of the lithification field in Fig. $14 \mathrm{C}$. The $\delta^{13} \mathrm{C}$ values of whole-rock marlstones are similar or slightly more negative than their marine equivalent (Eocene marine benthic foraminifera, Cramer et al., 2009), whereas $\delta^{18} \mathrm{O}$ values are significantly more negative (Fig. 14C). The timing and depth of lithification are not well constrained, however, Hoareau et al. (2015) suggested that lithification took place at temperatures below $50^{\circ} \mathrm{C}$ for the slope deposits of the Sobrarbe delta. They found several phases of diagenesis preceding or coeval with lithification formed in equilibrium with pore water of marine origin. Later stages of diagenesis identified in veins and foraminifera were characterized by fluids indicating a mixture of meteoric and seawater (Hoareau et al., 2015). Thus, the exact composition of pore water during lithification remains unconstrained, however, we propose a mainly marine origin as cementation at equilibrium with meteoric water would have produce a larger scatter of the data, similar to the one observed in diagenetic endmembers such as calcite and dolomitic cements found in the Hecho Group (Fig. 14C; Travé et al., 1997; Mansurbeg et al., 2009). Furthermore, clays-rich marlstones, distant from veins or concretions, probably acted as closed diagenetic systems by their low porosity and permeability trapping seawater in pore space during burial. The formation of new phases in equilibrium with seawater at 

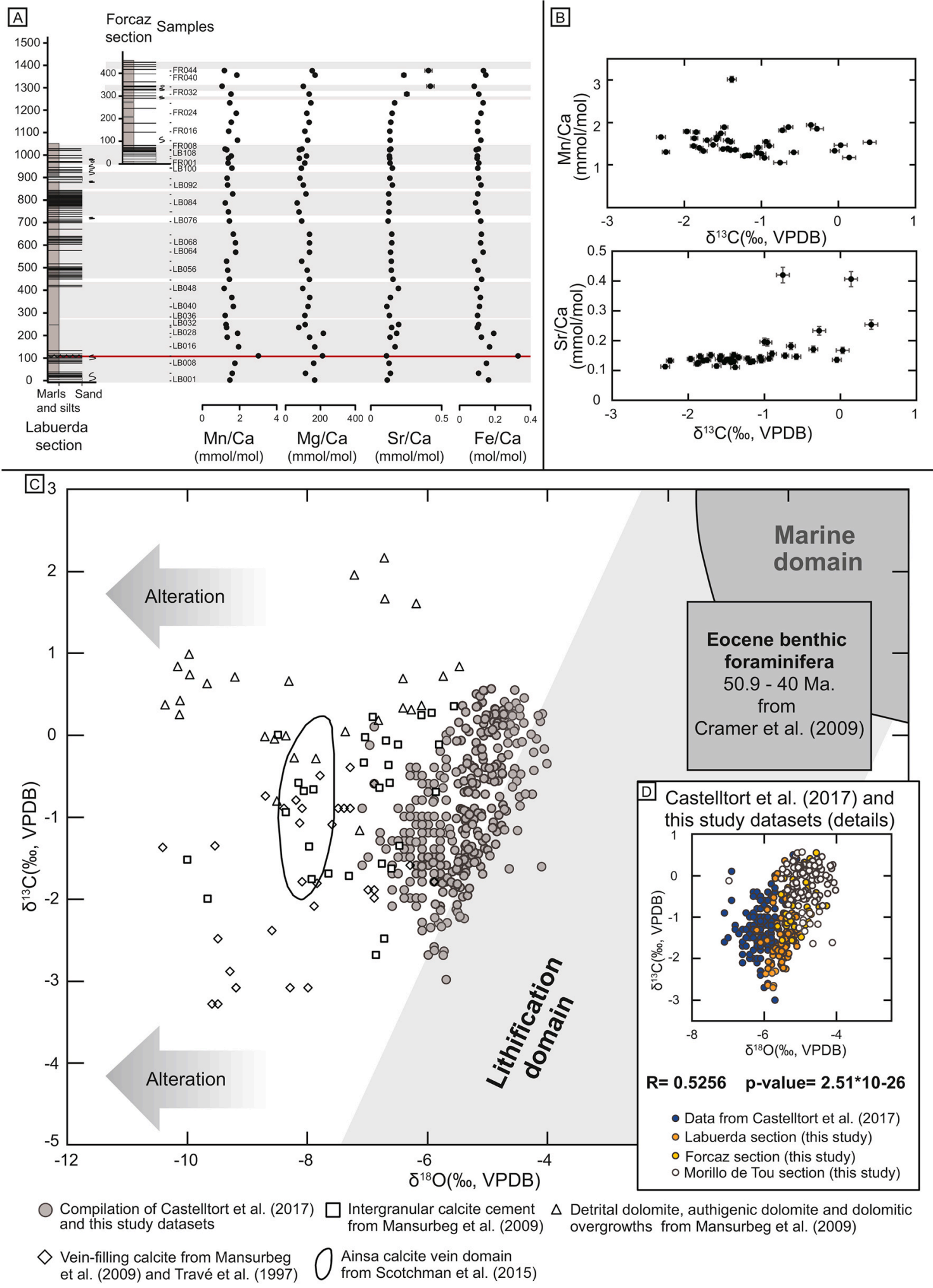

Fig. 14. Evaluation of diagenesis. (A) $\mathrm{Mn} / \mathrm{Ca}, \mathrm{Sr} / \mathrm{Ca}, \mathrm{Mg} / \mathrm{Ca}$ and $\mathrm{Fe} / \mathrm{Ca}$ against depth for Forcaz and Labuerda sections. Note the low variability of these records. (B) Cross-plots showing the lack of correlation between $\mathrm{Mn} / \mathrm{Ca}$ and $\mathrm{Sr} / \mathrm{Ca}$ with $\delta^{13} \mathrm{C}$. (C) Cross-plot of $\delta^{13} \mathrm{C}$ versus $\delta^{18} \mathrm{O}$ (Lithification and marine domains from Knauth and Kennedy, 2009). Note the general scatter of diagenetic phases indicated by triangles, squares, and diamonds in comparison with carbonate mudstones (circle). (D) Details of the compilation of Castelltort et al. (2017) and this study datasets.

higher temperature relative to the surface, could explain the large shift observed in $\delta^{18} \mathrm{O}$ values with depth (Fig. 14D; Marshall, 1992). Due to the lower sensitivity of the $\delta^{13} \mathrm{C}$ values to temperature, and the moderate increase in temperature during burial (e.g., Marshall, 1992), a primary environmental $\delta^{13} \mathrm{C}$ signal is well preserved in closed systems or systems with restricted inflow of postdepositional fluids. Additionally, in the scenario of lithification at shallow depth and because of the similarities between 
local and global $\delta^{18} \mathrm{O}$ records, the preservation of primary environmental $\delta^{18} \mathrm{O}$ signals cannot be completely ruled out.

(3) The total amount and type (terrestrial or marine) of organic matter buried can affect the $\delta^{13} \mathrm{C}$ of dissolved inorganic carbon (DIC) in pore fluids (e.g., Marshall, 1992). In this study, the low variability in the TOC contents and the organic matter of predominantly terrestrial origin (type III kerogen, Fig. 9) does not seem to explain variations in the carbonate $\delta^{13} \mathrm{C}$ values.

(4) Strontium, manganese, iron, and magnesium can be used to trace diagenetic processes in carbonate rocks due to their divergent behaviors during burial (Brand and Veizer, 1980). Manganese and iron are usually enriched in meteoric waters with respect to seawater and tend to be enriched in newly formed diagenetic phases (Brand and Veizer, 1980). Conversely, strontium and magnesium are depleted in meteoric fluids (Travé et al., 1997). Thus, new phases formed during diagenesis tend to have lower $\mathrm{Sr} / \mathrm{Ca}$ and $\mathrm{Mg} / \mathrm{Ca}$ ratios. In the upper Hecho Group, Fig. 14A shows that the ratio of these elements over calcium remains stable in the Labuerda and Forcaz sections. The lack of variability of these ratios suggests that, if present, the signature of diagenesis is homogenous on the marlstones, or restricted to veins and concretions. This assumption is confirmed by the lack of correlation between $\mathrm{Sr} / \mathrm{Ca}$ or $\mathrm{Mn} / \mathrm{Ca}$ and $\delta^{13} \mathrm{C}$ (Fig. 14B). Interestingly, an increase in the $\mathrm{Sr} / \mathrm{Ca}$ ratio is observed around $300 \mathrm{~m}$ in the Forcaz section which could suggest lower diagenesis (Fig. 14A). This interval is also characterized by a $\delta^{13} \mathrm{C}$ of around $0.1 \%$ and a $\delta^{18} \mathrm{O}$ approximately $-4.9 \%$ consistent with less alteration (Fig. 9). However, the increase of $\delta^{13} \mathrm{C}$ values from $-1.5 \%$ to $0.1 \%$ (100 to $300 \mathrm{~m}$, Forcaz section, Fig. 9) is initiated before the increase in $\mathrm{Sr} / \mathrm{Ca}$. Thus, relative changes in the carbon isotopic record cannot be directly linked to diagenesis.

(5) Significant dolomitization can be excluded in the upper Hecho Group because dolomite abundance is low in the Forcaz and
Labuerda section (average $=2.89 \%$ ) and lacks correlation with $\delta^{13} \mathrm{C}$ values (Pearson's $\mathrm{R}=0.01$ for data where dolomite abundance is above detection limit; See Supplementary material I, Fig. S.4.3).

A complete facies analysis of the hemipelagic deposits of the studied succession would be necessary to completely ruled out an impact of diagenesis on isotopic records, such work would however be beyond the scope of this study. The lack of evident relationship between isotopic records and proxies for diagenetic processes suggests a preservation of primary environmental signal.

\subsubsection{Local isotope signal versus global records}

The new age model based on magnetostratigraphy and biostratigraphy was used to tune the isotope dataset. If preserved, the primary carbon and oxygen isotope composition of the whole-rock carbonates, which precipitated in equilibrium with the DIC, will reflect the isotopic signal of the surrounding oceanic water. Therefore, the $\delta^{13} \mathrm{C}$ and $\delta^{18} \mathrm{O}$ data were compared to global isotope target curves (Cramer et al., 2009, recalibrated to GTS 2012; Gradstein et al., 2012, by Grossman, 2012a,b) and eustatic global records (Miller et al., 2005; Kominz et al., 2008) in order to explore the origin of the isotope signal and the possible relationship between stratigraphy and sea-level variations (Fig. 15).

5.3.2.1. Oxygen isotopes. Oxygen isotopes are well known to be a proxy for paleotemperatures (e.g., Lisiecki and Raymo, 2005). The middle Eocene climate is characterized by transient conditions from greenhouse to icehouse climate (e.g., Tripati et al., 2005) with indicators of development of Antarctic ice sheets (e.g., Pekar et al., 2005). During the deposition of the upper Hecho Group, the climate underwent a progressive cooling initiated after the Early Eocene Climate Optimum (EECO, $\sim 49 \mathrm{Ma}$ ). This progressive cooling was interrupted by the global Middle Eocene Climatic Optimum event (MECO), which followed the

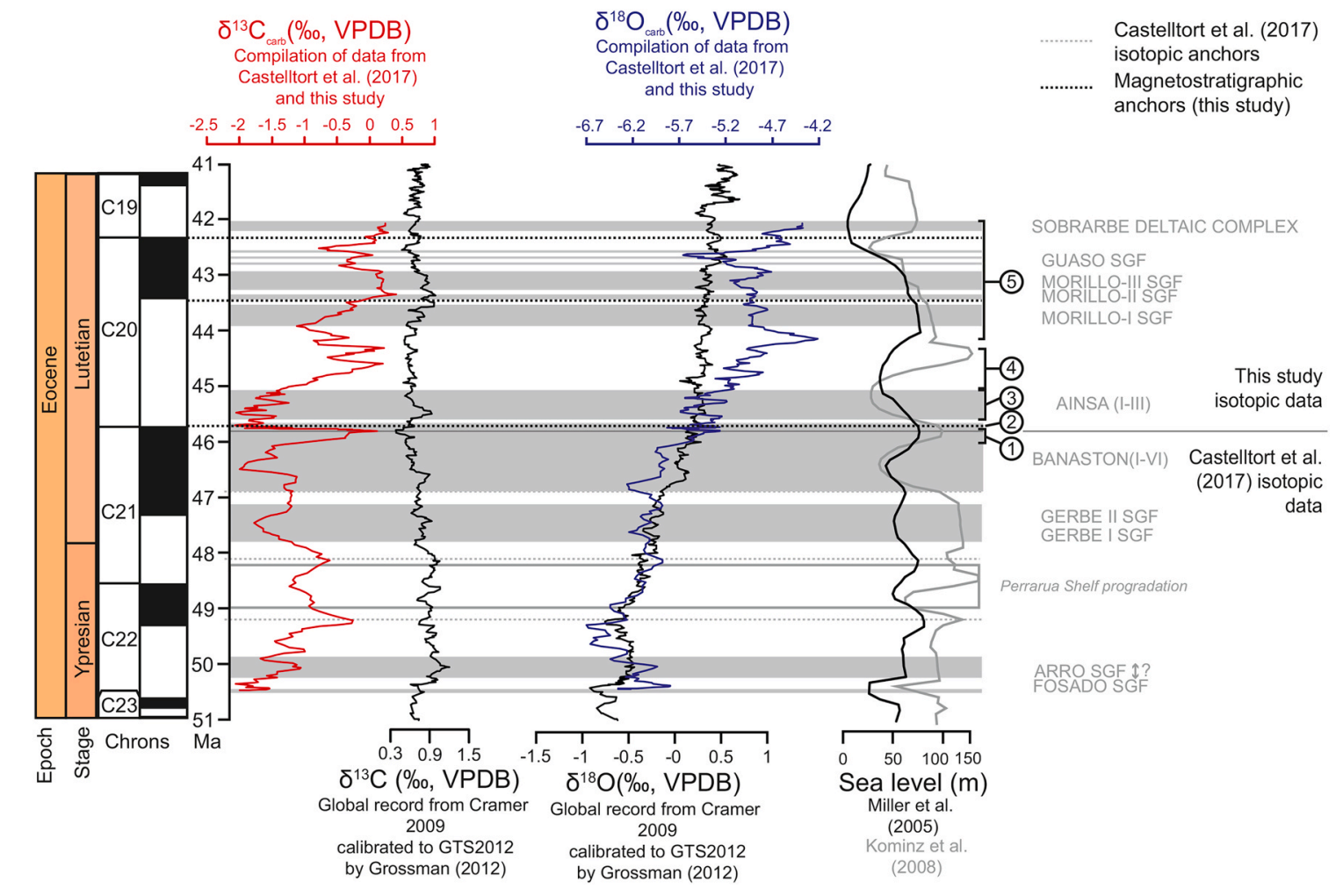

Fig. 15. Comparison of isotope values calibrated and global records (Isotopes: Cramer et al., 2009; Sea level: Miller et al., 2005 and Kominz et al., 2008). Note the link between lowstands/regressions and activity of SGF systems. Numbers on the right refer to points mentioned in sec. 5.3.2.2.Global records are indicated with a 9-points moving average. Local datasets are displayed with a 5-points moving average. 
deposition of the Hecho Group (ca. 40.5 Ma to 40 Ma; Sluijs et al., 2013; Westerhold and Röhl, 2013; Boscolo Galazzo et al., 2014). During the deposition of the Hecho Group, the general trend toward more positive $\delta^{18} \mathrm{O}$ values (Fig. 15) could be explained by a gradual cooling that mirrors the global record. The progressive shift in the oxygen isotope record is only interrupted by a negative excursion in the Guaso SGF system, possibly reflecting a local warming event or a restriction of the connectivity in the basin that would enhance the influx of meteoric waters signal from the continent. A detailed petrographic description of the marlstones would be necessary to decipher diagenetic (see sec. 5.3.1 Effect of diagenesis) and climatic imprint on the $\delta^{18} \mathrm{O}$ record. Such work would go beyond the scope of this study focusing on carbon isotope record.

5.3.2.2. Carbon isotopes. The $\delta^{13} \mathrm{C}$ values of the Hecho Group show discrepancies with the global record of Cramer et al. (2009; Fig. 15). Large-scale shifts are observed in the marlstones of the Ainsa basin $\left(\delta^{13} \mathrm{C}\right.$ values varying between -3 and $0.56 \%$; Fig. 11) whereas the global carbon isotope signal remains stable between ca 50.5 and $42 \mathrm{Ma}\left(\delta^{13} \mathrm{C}\right.$ values ranging between 0.38 and $1.2 \%$; Cramer et al., 2009 recalibrated to GTS2012 by Grossman, 2012a,b). Such variations and the proximal position of the basin during the time of deposition suggest a local imprint in the isotopic record (Saltzman et al., 2012). In the vicinity of the continental margin, variations in the carbon isotope composition of DIC and carbonates can result from (1) changes in productivity and burial rate of organic matter triggered by sea-level changes, (2) discharge of fresh water and nutrients from terrestrial runoff, (3) changes in the stratification of the water column, the water circulation pattern, and depositional environment, and (4) inputs of detrital carbonates with distinct $\delta^{13} \mathrm{C}$ and $\delta^{18} \mathrm{O}$ values.

(1) An increase in primary productivity together with higher organic matter burial on the shelf is often observed during transgression and sea-level highstands (e.g., Jenkyns, 1996). Both processes efficiently remove ${ }^{12} \mathrm{C}$ from seawater and trigger positive excursions in the $\delta^{13} \mathrm{C}$ values of carbonates (e.g., Scholle and Arthur, 1980; Jenkyns and Clayton, 1986; Arthur et al., 1987; Jenkyns, 1996; Marshall, 1992; Jarvis et al., 2002). Conversely, regressions are often characterized by strengthening the reworking of shelf organic matter and releasing ${ }^{12} \mathrm{C}$-enriched carbon into the DIC reservoir (Jenkyns, 1996; Jarvis et al., 2002). Thus, a relationship between sea level and the $\delta^{13} \mathrm{C}$ values can often be established (Scholle and Arthur, 1980; Arthur et al., 1987; Jenkyns et al., 1994; Jenkyns, 1996). More complex interactions between sea level and carbon isotopes were also observed (Jarvis et al., 2001; Voigt, 2000). For instance, Harper et al. (2015) described the export of siliciclastic sediments from the shelf to the slope during sea-level rise. The flooding of shallow-water carbonate factories due to a rapid sea-level rise could also impact $\delta^{13} \mathrm{C}$ values of the DIC (Jarvis et al., 2002). Finally, a release of methane, probably caused by pressure changes at the ocean floor, could cause a negative excursion of the $\delta^{13} \mathrm{C}$ record (e.g., Dickens et al., 1995; Hesselbo et al., 2000).

(2) High influx of freshwater with ${ }^{12} \mathrm{C}$-enriched DIC compared to seawater combined with enhanced oxidation of organic matter from continental margins during regression could lower the $\delta^{13} \mathrm{C}$ values (Jenkyns et al., 1996).

(3) The $\delta^{13} \mathrm{C}$ signature of DIC varies with water depth. At shallow water depth, high productivity and the preferential uptake of ${ }^{12} \mathrm{C}$ by organisms cause a relative increase in the $\delta^{13} \mathrm{C}$ of the DIC. At deeper water depth, oxidation of sinking organic matter releases ${ }^{12} \mathrm{C}$ in seawater. The $\delta^{13} \mathrm{C}$ values of the DIC decrease accordingly (e.g., Kroopnick, 1985; Marshall, 1992). Therefore, stratification of the water column and associated oxic-anoxic regimes can affect the $\delta^{13} \mathrm{C}$ values.
(4) Finally, a significant input of detrital carbonates could cause shifts in the $\delta^{13} \mathrm{C}$ values.

In the Hecho Group, the petrographic description of the sandstones of the SGF systems by Gupta and Pickering (2008) showed that the proportion of extrabasinal carbonated grains remains low in the systems of the Hecho Group (Fosado: average value of 2\%, Arro: $2 \%$, Gerbe: 0.9\%, Banaston: 3\%, Ainsa: 5\%, Morillo: $13 \%$, and Guaso: $10 \%$ ). The slight increase of extrabasinal carbonated grains in Morillo and Guaso is considered negligible in the marlstones composed of approximately $50 \%$ of micritic calcite and $50 \%$ of detrital grains (marlstones samples from the slope deposits of the Sobrarbe delta complex; Hoareau et al., 2009, 2015).

The $\delta^{13} \mathrm{C}$ values in the Hecho Group were compared to the eustatic global records of Miller et al. (2005) and Kominz et al. (2008). Due to limitations in the resolution of both records and the discrepancies between the two curves, eustatic changes are considered here as phase values rather than absolute values. In the Pueyo off-axis section, a robust correlation was found between the sea level and the $\delta^{13} \mathrm{C}$ values from Fosado SGF system to Banaston SGF system $(R=0.81$, Castelltort et al., 2017, Fig. 15). To explain the observed correlation between negative (respectively positive) carbon isotope excursions and sea-level regressions (respectively transgressions), Castelltort et al. (2017) invoked the influx of freshwaters with low $\delta^{13} \mathrm{C}$-DIC to the site of deposition during lowstands and higher $\delta^{13} \mathrm{C}$ DIC during transgressions, caused by enhanced burial of organic matter (depleted in ${ }^{13} \mathrm{C}$ ) on the shelf (Jenkyns, 1996).

From Banaston II? SGF system to the distal deposits of the Sobrarbe deltaic complex (see Fig. 15), the trends highlighted in Castelltort et al. (2017) can still be recognized for most of the SGF systems.

(1) Banaston-II? shows a positive excursion during a sea-level highstand coherent with the patterns found in Castelltort et al. (2017); point 1 in Figs. 9 and 15). It is interesting to note that B-II? lateral deposits are related to an input of reworked, eroded, or oxidized organic matter (type IV kerogen, Fig. 9).

(2) Banaston-III to VI SGF systems are characterized by a negative excursion of $\delta^{13} \mathrm{C}$ values that can be associated with the initiation of a global regression (point 2, in Fig. 9 and 15). The sharp transition from a positive $\delta^{13} \mathrm{C}$ excursion in B-II? to a negative $\delta^{13} \mathrm{C}$ excursion in B-III is coeval with an increase in grain size (See Supplementary material I, Fig.S.4.1., Si/Al, Ti/Al, and Zr/Al ratios), and took place close to a turning point in the sea-level curve (Fig. 15). A sea-level decrease could have enhanced the influx of coarse grains and ${ }^{12} \mathrm{C}$-enriched freshwaters to deep marine settings, leading to a negative excursion in $\delta^{13} \mathrm{C}$ values.

(3) In the lateral deposits of the sandbodies of the Ainsa SGF system (A-I and A-II, point 3 in Figs. 9 and 15), the measured negative $\delta^{13} \mathrm{C}$ excursion is coupled with a global regression.

(4) The marlstone interval between Ainsa II and the heterolithic beds identified at the top of the Forcaz section (point 4 in Figs. 9 and 15) are characterized by a gradual increase in $\delta^{13} \mathrm{C}$ values. Although our age model is poorly constrained for this interval, the higher HI values (Fig. 11, red rectangle) and the repeated occurrence of type II kerogen (Fig. 9) suggest a dominant marine influence. A progressive increase in $\delta^{13} \mathrm{C}$ values and the general fining-upward observed in this interval (see Supplementary material I, Fig.S.4.1., Si/Al, Ti/Al, and $\mathrm{Zr} / \mathrm{Al}$ ratios) would be consistent with more storage on the shelf as the sea-level rises after 44.8 Ma.

Despite the tectonically active setting of the Ainsa basin during the Eocene and the possible discrepancies between relative sea-level changes and eustatism, the systematic relationship described above suggests a dominant imprint of eustatism on carbon isotopic records. We thus propose a link between $\delta^{13} \mathrm{C}$ values and eustatism as a highly 
plausible scenario to explain our record.

From Morillo SGF system to the Sobrarbe deltaic complex (point 5 in Figs. 9 and 15), the $\delta^{13} \mathrm{C}$ signal does not mirror the trends predicted by Castelltort et al. (2017). Here, high $\delta^{13} \mathrm{C}$ values are linked to a global regression. The tectonic history, with the progressive integration of the basin into the wedge-top and its transformation into a piggy-back basin (Vinyoles et al., 2021), and global eustatic curves point toward a relative sea-level decrease. A transition from deep marine environments, where $\delta^{13} \mathrm{C}$ DIC is controlled by oxidation of organic matter and input from proximal settings, to shallower water characterized by high productivity and high $\delta^{13} \mathrm{C}$ DIC (Marshall, 1992) could explain such trends. Similarly, a restriction in ocean circulation related to the growth of the Boltaña anticline (Heard et al., 2008) and severe anoxic conditions in the water column could trigger higher $\delta^{13} \mathrm{C}$ values. The occurrence of major darker levels (e.g., San Lino level) and slightly higher TOC contents recorded in the marlstones of Morillo and Guaso ( $0.32 \mathrm{wt} \%$ vs. preceding $0.24 \mathrm{wt} \%$ on average, Fig. 9) is consistent with this scenario. A decrease in the oxygenation of the basin suggests the $\mathrm{Th} / \mathrm{U}$ values recorded in the Morillo and Guaso SGF systems (Cantalejo and Pickering, 2015). Testing in more detail these scenarios would require $\delta^{13} \mathrm{C}_{\text {org }}$ measurements not performed within the scope of this study.

In conclusion, our isotopic data seem to indicate that the relation between sea level and the stable carbon record highlighted in Castelltort et al. (2017) is robust, as long as there is no significant change in the environment of deposition or in the geomorphology of the basin (e.g., restriction in the water circulation due to the growth of anticlines). It is interesting to note that carbonates isotope composition responds relatively fast to sea-level changes, as shown by the drastic decrease in the $\delta^{13} \mathrm{C}$ values associated with the turning point in the sea-level curve at ca. 47.5 Ma (Miller et al., 2005; Kominz et al., 2008).

\subsection{Pulses of sand delivery versus global sea-level record}

The structural conditions during the deposition of the Hecho Group in the Ainsa basin are well constrained (Vinyoles et al., 2021). The deposition of Fosado SGF system is coeval with the major fluvial progradation and incision of the Castissent Fm linked, in literature, to thrust activities, a pulse in exhumation rates (Puigdefàbregas and Souquet, 1986; Whitchurch et al., 2011; Chanvry et al., 2018) and a sea-level fall/lowstand ((Puigdefàbregas and Souquet, 1986)Marzo et al., 1988; Pickering and Bayliss, 2009; Castelltort et al., 2017). Subsequently, the Arro SGF system, also formed by the erosion of the Castissent Fm, is deposited during a sea-level highstand in Castelltort et al. (2017). Castelltort et al., 2017 hypothesized the deposition of the Arro SGF system to be driven by an increase in exhumation rates in the Pyrenees. This hypothesis was refined by Thomson et al. (2017) detrital zircon (U-Th)/He ages, which suggested a short-frequency climatic or tectonic pulse. Recently, Cantalejo et al. (2020a) proposed a younger age for the Arro system by identifying the nannofossil Subzone NP14a, making more difficult a direct linkage between stratigraphy and eustatism.

Gerbe I and II are the response to the Montsec thrust sheet emplacement and a significant rate of relief growth in the Axial Zone. This system is linked to the deposition of the Campanue Conglomerates (Mutti et al., 1985; Muñoz et al., 2013; Arbués et al., 2011; Scotchman et al., 2015a). Finally, Banaston to Guaso systems of the Hecho Group were deposited during the growth of the Mediano and the Boltaña anticlines associated with the Sobrarbe Fold system (Muñoz et al., 2013). In these structural conditions controlling the large geometries of deposition, the accommodation, and the supply of sediments to the shelf, a comparison of global sea-level curves and the stratigraphic records of the Ainsa basin still suggests eustasy as an essential driver in delivering coarse sediments to deep-waters.

In the Pueyo off-axis section tuned by the isotopic record, Fosado, Gerbe I and II, and Banaston I members are systematically deposited during sea-level lowstands. Additionally, Banaston III to IV, Ainsa, Morillo, and Guaso systems are deposited during regressive events.
Notably, Banaston III to VI and the Ainsa members were deposited during the regressive event from ca $45.8 \mathrm{Ma}$ to $44.9 \mathrm{Ma}$ (Fig. 15). Morillo, Guaso SGF systems, and the distal deposits of the Sobrarbe deltaic complex were deposited between $44 \mathrm{Ma}$ to $42 \mathrm{Ma}$, during the subsequent regressive event (Fig. 15). The only exceptions to these systematic depositions during sea-level regressions and lowstands are the Arro SGF system (see above) and Banaston II? member, possibly associated with a sea-level rise and/or a highstand. Interestingly, Gupta and Pickering (2008) showed that the abundance of intrabasinal carbonate grains is higher in these two SGF systems (average of $16 \%$ for Arro system and $11 \%$ for Banaston system; Gupta and Pickering, 2008) than in the remaining systems of the basin $(1.2 \%$ for Fosado, $2 \%$ for Gerbe, approximately 9\% for Ainsa, 4\% for Morillo, and 3\% for Guaso system; Gupta and Pickering, 2008). Intrabasinal carbonate grains are sourced from coeval carbonates platforms on the shelf and/or the erosion of older carbonates on the Mediano and Boltaña structures (Gupta and Pickering, 2008). The development of these tectonic structures could explain the deposition of B-II? system in the context of a high sea-level stand. Finally, the thick marlstones interval between Ainsa and Morillo systems (point 4 in Figs. 9 and 15) is associated with an extensive transgressive period. The preferential deposition of sandstones enriched sediments during sea-level lowstands or regressive events, and vice versa thick marlstone intervals during transgressive events, suggests that in the Ainsa basin sedimentary fill, eustatic variations played a major role in the deposition of clastic sediments.

\section{Conclusions}

We highlight the importance of studying deep-sea environments by a multi-proxy approach to disentangle complex signals recorded in settings (such as the deep-marine) with a high preservation potential.

This study provides a new age model for the deep marine sediment gravity flow deposits of the upper Hecho Group (from Banaston SGF system to the distal deposits of the Sobrarbe deltaic complex) in the Ainsa basin (southern central Pyrenees). It integrates Castelltort et al. (2017) dataset from Fosado to Banaston SGF systems with magnetostratigraphic and biostratigraphic constraints from Banaston SGF system to the distal deposits of the Sobrarbe deltaic complex in the deep marine stratigraphic series of the Ainsa basin.

New magnetostratigraphic data are corroborated by biostratigraphy suggesting magnetozones C21n, C20r, C20n, and C19r for the sediments deposited from the Banaston SGF system to the Sobrarbe deltaic complex. New biostratigraphic sites strengthened this interpretation by detecting NP16 for two locations in the Guaso SGF system. Our new integrated data indicate a deposition age of $45.72 \mathrm{Ma}$ for the Banaston IV SGF system, 43.43 Ma for the Morillo II SGF system, and 42.3 Ma for the distal deposits of the Sobrarbe delta. These results give relative constant net sediment accumulation rates of (1) $54.1 \mathrm{~cm} / \mathrm{kyr}$ between Banaston III or IV and Morillo II, and (2) $51.5 \mathrm{~cm} / \mathrm{kyr}$ between Morillo II and the distal members of the Sobrarbe delta.

These chronostratigraphic constraints were used to correlate the isotope records and compare them with global "targets" curves. While oxygen isotope might be overprinted by diagenesis, the carbon isotope local signal seems to be preserved and controlled by sea-level modulations as long as the waters circulation is not restricted and/or as long as the environment of deposition does not change. A mismatch between the local isotope curve and the eustatic variations was observed for Morillo and Guaso SGF systems that might be explained by a partial restriction in water circulation or a transition to shallower environments.

Finally, despite the complex tectonic setting of the Ainsa basin during the deposition of the Hecho Group, a trend can be detected between the deposition of sandstone enriched sediments and global eustatic variations. Most SGF systems (Fosado, Gerbe, Ainsa, Morillo, and Guaso) and the distal deposits of the Sobrarbe deltaic complex are preferentially deposited during sea-level falls or lowstands. Respectively, major marlstones intervals are deposited during transgressive events. The only 
exceptions might be Arro SGF system possibly associated with a climatic and a tectonic pulse, and Banaston II member associated with the growth of tectonic structures in the basin.

\section{Declaration of competing interest}

The authors declare that they have no known competing financial interests or personal relationships that could have appeared to influence the work reported in this paper.

\section{Acknowledgements}

This work was supported by an Augustin Lombard Grant from the SPHN Society of Geneva [grant Augustin Lombard, 2016, to Läuchli], a Equinor grant to Castelltort and a MINECO spanish project CGL201455900 to Garcés. Thanks to the Paleomagnetic Laboratory CCiTUBICTJA CSIC where the paleomagnetic analyses were conducted. Many thanks also to Fabio Capponi for XRF analyses and Andreu Vinyoles for support on the field.

\section{Appendix A. Supplementary data}

Supplementary data to this article can be found online at https://doi. org/10.1016/j.marpetgeo.2021.105182.

\section{Data availability}

Datasets presented in this article can be found in the Supplementary material II.

\section{References}

Arbués, P., Mellere, D., Falivene, O., Fernández-Bellón, O., Muñoz, J.A., Marzo, M., de Gibert, J.M., 2007. Context and architecture of the ainsa-1-quarry channel complex, Spain, in atlas of deep-water outcrops. In: Nilsen, T.H., et al. (Eds.), AAPG Studies in Geology, vol. 56. AAPG-Shell Explor. and Prod., Tulsa, Okla, p. 20.

Arbués, P., Butillé, M., López-Blanco, M., Marzo, M., Monleón, O., Muñoz, J.A., SerraKiel, J., 2011. Exploring the relationships between deepwater and shallow-marine deposits in the aínsa piggy back basin fill (Eocene, south Pyrenean foreland basins). In post-meeting field trips guidebook, 28th IAS meeting, zaragoza. In: Arenas, C., Pomar, L., Colombo, F. (Eds.), Sociedad Geológica de España: Salamanca, Spain, vol 8. Geo-Guías, pp. 199-238.

Arthur, M.A., Schlanger, S.T., Jenkyns, H.C., 1987. The Cenomanian-Turonian Oceanic Anoxic Event, II. Palaeoceanographic controls on organic-matter production and preservation. Geological Society, London, Special Publications 26 (1), 401-420.

Barnolas, A., Gil-Peña, I., 2001. Ejemplos de relleno sedimentario multiepisódico en una cuenca de antepaís fragmentada: La Cuenca Surpirenaica. Bol. Geol. Min. 112 (3), 17-38.

Beaumont, C., Muñoz, J.A., Hamilton, J., Fullsack, P., 2000. Factors controlling the Alpine evolution of the central Pyrenees inferred from a comparison of observations and geodynamical models. J. Geophys. Res.: Solid Earth 105 (B4), 8121-8145. https://doi.org/10.1029/1999JB900390.

Bentham, P.A., 1992. The Tectono-Stratigraphic Development of the Western Oblique Ramp of the South-Central Pyrenean Thrust System, Northern Spain. Ph. D. thesis, University of Southern California, p. 253.

Bentham, P.A., Burbank, D.W., Puigdefàbregas, C., 1992. Temporal and spatial controls on the alluvial architecture of an axial drainage system: late Eocene Escanilla Formation, southern Pyrenean foreland basin, Spain. Basin Res. 4, 335-352.

Bentham, P., Burbank, D.W., 1996. Chronology of Eocene foreland basin evolution along the western oblique margin of the South-Central Pyrenees. In: Friend, P.F., Dabrio, C J. (Eds.), Tertiary Basins of Spain. The Stratigraphic Record of Curstal Kinematics. Cambridge University Press, pp. 144-152.

Bouma, A.H., Normark, W.R., Barnes, N.E., 1985. Submarine Fans and Related Turbidite Systems. Springer-Verlag, Berlin, p. 343.

Boscolo Galazzo, F., Thomas, E., Pagani, M., Warren, C., Luciani, V., Giusberti, L., 2014. The middle Eocene climatic optimum (MECO): a multiproxy record of paleoceanographic changes in the southeast Atlantic (ODP Site 1263, Walvis Ridge). Paleoceanography 29 (12), 1143-1161. https://doi.org/10.1002/2014PA002670.

Brand, U., Veizer, J., 1980. Chemical diagenesis of a multicomponent carbonate system; 1, Trace elements. J. Sediment. Res. 50 (4), 1219-1236. https://doi.org/10.1306/ 212F7BB7-2B24-11D7-8648000102C1865D.

Brand, U., Veizer, J., 1981. Chemical diagenesis of a multicomponent carbonate system; 2, Stable isotopes. J. Sediment. Res. 51 (3), 987-997. https://doi.org/10.1306/ 212F7DF6-2B24-11D7-8648000102C1865D.

Cantalejo, B., Pickering, K.T., 2014. Climate forcing of fine-grained deep-marine systems in an active tectonic setting: middle Eocene, Ainsa Basin, Spanish Pyrenees.
Palaeogeogr. Palaeoclimatol. Palaeoecol. 410, 351-371. https://doi.org/10.1016/j. palaeo.2014.06.005.

Cantalejo, B., Pickering, K.T., 2015. Orbital forcing as principal driver for fine-grained deep-marine siliciclastic sedimentation, Middle-Eocene Ainsa Basin, Spanish Pyrenees. Palaeogeogr. Palaeoclimatol. Palaeoecol. 421, 24-47. https://doi.org/ 10.1016/j.palaeo.2015.01.008.

Cantalejo, B., Pickering, K.T., McNiocaill, C., Bown, P., Johansen, K., Grant, M., 2020a. A revised age-model for the Eocene deep-marine siliciclastic systems, Ainsa Basin, Spanish Pyrenees. J. Geol. Soc. https://doi.org/10.1144/jgs2019-131.

Cantalejo, B., Pickering, K.T., Miller, K.G., Mac Niocaill, C., 2020b. Chasing the $400 \mathrm{kyr}$ pacing of deep-marine sandy submarine fans: middle Eocene Aínsa Basin, Spanish Pyrenees. J. Geol. Soc. 178 (1) https://doi.org/10.1144/jgs2019-173.

Castelltort, S., Van Den Driessche, J., 2003. How plausible are high-frequency sediment supply-driven cycles in the stratigraphic record? Sediment. Geol. 157 (1-2), 3-13. https://doi.org/10.1016/S0037-0738(03)00066-6.

Castelltort, S., Honegger, L., Adatte, T., Clark, J.D., Puigdefàbergas, C., Spangenberg, J. E., Dykstra, M.L., Fildani, A., 2017. Detecting eustatic and tectonic signals with carbon isotopes in deep-marine strata, Eocene Ainsa Basin, Spanish Pyrenees. Geology 45 (8), 707-710. https://doi.org/10.1130/G39068.1.

Chanvry, E., Deschamps, R., Joseph, P., Puigdefàbregas, C., Poyatos-Moré, M., SerraKiel, J., Garcia, D., Teinturier, S., 2018. The influence of intrabasinal tectonics in the stratigraphic evolution of piggyback basin fills: towards a model from the TrempGraus-Ainsa Basin (South-Pyrenean Zone, Spain). Sediment. Geol. 377, 34-62.

Choukroune, P., 1992. Tectonic evolution of the pyrenees. Annu. Rev. Earth Planet Sci. 20, 143-158.

Clark, J., Puigdefàbregas, C., Castelltort, S., Fildani, A., 2017. Propagation of Environmental Signals within Source-To-Sink Stratigraphy: Spanish Pyrenees. SEPM (Society for Sedimentary Geology.

Cornard, P.H., Pickering, K.T., 2019. Supercritical-flow deposits and their distribution in a submarine channel system, middle Eocene, Ainsa basin, Spanish pyrenees. J. Sediment. Res. 89 (6), 576-597. https://doi.org/10.2110/jsr.2019.34.

Costa, E., Garcés, M., López-Blanco, M., Beamud, E., Gómez-Paccard, M., Larrasoaña, J. C., 2010. Closing and continentalization of the South Pyrenean foreland basin (NE Spain): magnetochronological constraints. Basin Res. 22, 904-917.

Covault, J.A., Normark, W.R., Romans, B.W., Graham, S.A., 2007. Highstand fans in the California borderland: the overlooked deep-water depositional systems. Geology 35 (9), 783-786. https://doi.org/10.1130/G23800A.1.

Covault, J.A., Graham, S.A., 2010. Submarine fans at all sea-level stands: tectonomorphologic and climatic controls on terrigenous sediment delivery to the deep sea. Geology 38 (10), 939-942. https://doi.org/10.1130/G31081.1.

Cramer, B.S., Toggweiler, J.R., Wright, J.D., Katz, M.E., Miller, K.G., 2009. Ocean overturning since the Late Cretaceous: inferences from a new benthic foraminiferal isotope compilation. Paleoceanography 24 (4), 1-14. https://doi.org/10.1029/ 2008PA001683.

De Federico, A., 1981. La sedimentación de talud en el sector Occidental de la cuenca Paleógena de Aínsa, vol. 12. Universidad Autonoma de Barcelona Publicaciones de Geologia, p. 271.

Dickens, G.R., O'Neil, J.R., Rea, D.K., Owen, R.M., 1995. Dissociation of oceanic methane hydrate as a cause of the carbon isotope excursion at the end of the Paleocene. Paleoceanography 10 (6), 965-971.

Dreyer, T., Corregidor, J., Arbues, P., Puigdefàbregas, C., 1999. Architecture of the tectonically influenced Sobrarbe deltaic complex in the Ainsa Basin, northern Spain. Sediment. Geol. 127 (3-4), 127-169. https://doi.org/10.1016/S0037-0738(99) 00056-1.

Fernández, O., Muñoz, J.A., Arbués, P., Falivene, O., 2012. 3D structure and evolution of an oblique system of relaying folds: the Ainsa basin (Spanish Pyrenees). J. Geol. Soc. 169 (5), 545-559. https://doi.org/10.1144/0016-76492011-068.

Fillon, C., van der Beek, P., 2012. Post-orogenic evolution of the southern Pyrenees: constraints from inverse thermo-kinematic modelling of low-temperature thermochronology data. Basin Res. 24 (4), 418-436. https://doi.org/10.1111/ j.1365-2117.2011.00533.x.

Garcés, M., López-Blanco, M., Valero, L., Beamud, E., Muñoz, J.A., Oliva-Urcia, B., Vinyoles, A., Arbués, P., Cabello, P., Cabrera, L., 2020. Paleogeographic and sedimentary evolution of the South Pyrenean foreland basin. Mar. Petrol. Geol. 113, 104105. https://doi.org/10.1016/j.marpetgeo.2019.104105.

Gómez-Gras, D., Roigé, M., Fondevilla, V., Oms, O., Boya, S., Remacha, E., 2016. Provenance constraints on the Tremp formation paleogeography (southern pyrenees): Ebro massif VS pyrenees sources. Cretac. Res. 57, 414-427.

Gradstein, F.M., Ogg, J.G., Schmitz, M., Ogg, G. (Eds.), 2012. The Geologic Time Scale 2012, first ed. Set. Elsevier, pp. 2-Volume.

Grossman, E.L., 2012a. Chapter 10. Oxygen isotope stratigraphy. In: Gradstein, F., Ogg, J. (Eds.), Geological Time Scale 2012, first ed., 2-Volume Set. Elsevier, ISBN 9780444594259.

Grossman, E.L., 2012b. Geological time scale 2012. Chapter 10. Oxygen isotope stratigraphy. In: Gradstein, F., Ogg, J. (Eds.), Geological Time Scale 2012, first ed., 2Volume Set. Elsevier. Appendix 1., PANGEA,. https://doi.org/10.1594/PANGAEA 776989.

Gupta, K.D., Pickering, K.T., 2008. Petrography and temporal changes in petrofacies of deep-marine Ainsa-Jaca basin sandstone systems, Early and Middle Eocene, Spanish Pyrenees. Sedimentology 55 (4), 1083-1114.

Harper, B.B., Puga-Bernabéu, Á., Droxler, A.W., Webster, J.M., Gischler, E., Tiwari, M., Lado-Insua, T., Thomas, A., Morgan, S., Jovane, L., Röhl, U., 2015. Mixed carbonate-siliciclastic sedimentation along the great barrier reef upper slope: a challenge to the reciprocal sedimentation model. J. Sediment. Res. 85 (9), 1019-1036. 
Heard, T.G., Pickering, K.T., 2008. Trace fossils as diagnostic indicators of deep-marine environments, Middle Eocene Ainsa-Jaca basin, Spanish Pyrenees. Sedimentology 55 (4), 809-844. https://doi.org/10.1111/j.1365-3091.2007.00922.x.

Heard, T.G., Pickering, K.T., Robinson, S.A., 2008. Milankovitch forcing of bioturbation intensity in deep-marine thin-bedded siliciclastic turbidites. Earth Planet Sci. Lett. 272 (1-2), 130-138. https://doi.org/10.1016/j.epsl.2008.04.025.

Hesselbo, S.P., Gröcke, D.R., Jenkyns, H.C., Bjerrum, C.J., Farrimond, P., Bell, H.S.M., Green, O.R., 2000. Massive dissociation of gas hydrate during a Jurassic oceanic anoxic event. Nature 406 (6794), 392-395.

Hessler, A.M., Fildani, A., 2019. Deep-sea fans: tapping into Earth's changing landscapes. J. Sediment. Res. 89 (11), 1171-1179.

Heydari, E., Wade, W.J., Hassanzadeh, J., 2001. Diagenetic origin of carbon and oxygen isotope compositions of Permian-Triassic boundary strata. Sediment. Geol. 143 (3-4), 191-197.

Hoareau, G., Odonne, F., Debroas, E.J., Maillard, A., Monnin, C., Callot, P., 2009. Dolomitic concretions in the Eocene Sobrarbe delta (Spanish Pyrenees): fluid circulation above a submarine slide scar infilling. Mar. Petrol. Geol. 26 (5), 724-737. https://doi.org/10.1016/j.marpetgeo.2008.03.012.

Hoareau, G., Odonne, F., Garcia, D., Debroas, E.J., Monnin, C., Dubois, M., Potdevin, J. L., 2015. Burial diagenesis of the Eocene Sobrarbe delta (Ainsa Basin, Spain) inferred from dolomitic concretions. J. Sediment. Res. 85 (9), 1037-1057. https://doi.org/ 10.2110/jsr.2015.65.

Holl, J.E., Anastasio, D.J., 1993. Paleomagnetically derived folding rates, southern Pyrenees, Spain. Geology 21 (3), 271-274.

Jarvis, I.A.N., Murphy, A.M., Gale, A.S., 2001. Geochemistry of pelagic and hemipelagic carbonates: criteria for identifying systems tracts and sea-level change. J. Geol. Soc. 158 (4), 685-696.

Jarvis, I., Mabrouk, A., Moody, R.T., de Cabrera, S., 2002. Late Cretaceous (Campanian) carbon isotope events, sea-level change and correlation of the Tethyan and Boreal realms. Palaeogeogr. Palaeoclimatol. Palaeoecol. 188 (3-4), 215-248. https://doi. org/10.1016/S0031-0182(02)00578-3.

Jenkyns, H.C., Gale, A.S., Corfield, R.M., 1994. Carbon-and oxygen-isotope stratigraphy of the English Chalk and Italian Scaglia and its palaeoclimatic significance. Geol. Mag. 131 (1).

Jenkyns, H.C., 1996. Relative sea-level change and carbon isotopes: data from the upper Jurassic (Oxfordian) of central and Southern Europe. Terra. Nova 8 (1), 75-85. https://doi.org/10.1111/j.1365-3121.1996.tb00727.x.

Jenkyns, H.C., Clayton, C.J., 1986. Black shales and carbon isotopes in pelagic sediments from the Tethyan Lower Jurassic. Sedimentology 33 (1), 87-106. https://doi.org/ 10.1111/j.1365-3091.1986.tb00746.x.

Jones, R.W., Pickering, K.T., Boudagher-Fadel, M., Matthews, S., 2005. Preliminary observations on the micropalaeontological characterization of submarine fan/ channel subenvironments, Ainsa System, south-central Pyrenees, Spain. In: Powell, A.J., Riding, J.B. (Eds.), Recent Developments in Applied Biostratigraphy, vol. 1. The Micropalaeontological Society, Special Publication, pp. 55-68, 2005.

Knauth, L.P., Kennedy, M.J., 2009. The late Precambrian greening of the Earth. Nature 460 (7256), 728-732.

Kominz, M.A., Browning, J.V., Miller, K.G., Sugarman, P.J., Mizintseva, S., Scotese, C.R., 2008. Late Cretaceous to Miocene sea-level estimates from the New Jersey and Delaware coastal plain coreholes: an error analysis. Basin Res. 20, 211-226. https:// doi.org/10.1111/j.1365-2117.2008.00354.x.

Kroopnick, P.M., 1985. The distribution of 13C of $\Sigma \mathrm{CO} 2$ in the world oceans. Deep Sea Research Part A. Oceanographic Research Papers 32 (1), 57-84.

Labaume, P., Teixell, A., 2018. 3D structure of subsurface thrusts in the eastern Jaca Basin, southern Pyrenees. Geol. Acta 16 (4), 477-498. https://doi.org/10.1344/ GeologicaActa2018.16.4.9.

Lisiecki, L.E., Raymo, M.E., 2005. A Pliocene-Pleistocene stack of 57 globally distributed benthic d180 records. Paleoceanography 20 (1). https://doi.org/10.1029/ 2004PA001071.

Mansurbeg, H., Caja, M.A., Marfil, R., Morad, S., Remacha, E., Garcia, D., MartinCrespo, T., El-Ghali, M.A.K., Nystuen, J.P., 2009. Diagenetic evolution and porosity destruction of turbiditic hybrid arenites and siliciclastic sandstones of foreland basins: evidence from the Eocene Hecho Group, Pyrenees, Spain. J. Sediment. Res. 79 (9), 711-735.

Marshall, J.D., 1992. Climatic and oceanographic isotopic signals from the carbonate rock record and their preservation. Geol. Mag. 129 (2), 143-160.

Marzo, M., Nijman, W., Puigdefàbregas, C., 1988. Architecture of the Castissent fluvial sheet sandstones, Eocene, south Pyrenees, Spain. Sedimentology 35 (5), 719-738.

McCarthy, K., Rojas, K., Niemann, M., Palmowski, D., Peters, K., Stankiewicz, A., 2011. Basic petroleum geochemistry for source rock evaluation. Oilfield Rev. 23 (2), 32-43. https://doi.org/10.1016/j.epsl.2006.01.027.

Mey, P.H.W., Nagtegaal, P.J.C., Roberti, K.J., Hartevelt, J.J.A., 1968. Lithostratigraphic subdivision of post-Hercynian deposits in the south-central Pyrenees, Spain. Leidse Geol. Meded. 41 (1), 221-228.

Michael, N.A., Whittaker, A.C., Carter, A., Allen, P.A., 2014. Volumetric budget and grain-size fractionation of a geological sediment routing system: Eocene Escanilla Formation, south-central Pyrenees. Bull. Geol. Soc. Am. 126 (3-4), 585-599. https:// doi.org/10.1130/B30954.1.

Miller, K.G., Kominz, M.A., Browning, J.V., Wright, J.D., Mountain, G.S., Katz, M.E. Sugarman, P.J., Cramer, B.S., Christie-Blick, N., Pekar, S.F., 2005. The Phanerozoic record of global sea-level change. Science 310 (5752), 1293-1298. https://doi.org/ 10.1126/science.1116412.

Mochales, T., Barnolas, A., Pueyo, E.L., Serra-Kiel, J., Casas, A.M., Samsó, J.M., Sanjuán, J., 2012a. Chronostratigraphy of the boltaña anticline and the Ainsa Basin (southern pyrenees). Bull. Geol. Soc. Am. 124 (7-8), 1229-1250. https://doi.org/ 10.1130/B30418.1.
Mochales, T., Casas, A.M., Pueyo, E.L., Barnolas, A., 2012b. Rotational velocity for oblique structures (Boltaña anticline, Southern Pyrenees). J. Struc. Geol. 35, 2-16. https://doi.org/10.1016/j.jsg.2011.11.009.

Mouthereau, F., Filleaudeau, P.Y., Vacherat, A., Pik, R., Lacombe, O., Fellin, M.G., Castelltort, S., Christophoul, F., Masini, E., 2014. Placing limits to shortening evolution in the Pyrenees: role of margin architecture and implications for the Iberia/Europe convergence. Tectonics 33 (12), 2283-2314. https://doi.org/ 10.1002/2014TC003663.

Muñoz, J.A., 1992. Evolution of a continental collision belt: ECORS-Pyrenees crustal balanced cross-section. In: McClay, K.R. (Ed.), Thrust Tectonics. Springer, Dordrecht, pp. 235-246. https://doi.org/10.1007/978-94-011-3066-0_21.

Muñoz, J.A., Beamud, E., Fernández, O., Arbués, P., Dinarès-Turell, J., Poblet, J., 2013. The Ainsa Fold and thrust oblique zone of the central Pyrenees: kinematics of a curved contractional system from paleomagnetic and structural data. Tectonics 32 (5), 1142-1175. https://doi.org/10.1002/tect.20070.

Muñoz, J.A., Mencos, J., Roca, E., Carrera, N., Gratacós, O., Ferrer, O., Fernández, O. 2018. The structure of the South-Central-Pyrenean fold and thrust belt as constrained by subsurface data. Geol. Acta 16 (4), 439-460. https://doi.org/ 10.1344/GeologicaActa2018.16.4.7.

Mutti, E., Luterbacher, H.P., Ferrer, J., Rossell, J., 1972. Schema stratigrafico e lineamenti di facies del Paleogenemarino della zona centrale sudpirenaica tra Tremp (Catalogna) e Pamplona (Navarra). Mem. Soc. Geol. Ital. 11, 391-416.

Mutti, E., 1983. The Hecho Eocene submarine fan system, south-central Pyrenees, Spain. Geo Mar. Lett. 3, 199-202. https://doi.org/10.1007/BF02462468.

Mutti, E., Remacha, E., Sgavetti, M., Rosell, J., Valloni, R., Zamorano, M., 1985. Stratigraphy and facies characteristics of the Eocene Hecho Group turbidite systems, south-central Pyrenees. In: Mila, M.D., Rosell (Eds.), Excursion Guidebook of the 6th European Regional Meeting. International Association of Sedimentologists, Lleida, Spain, pp. 519-576.

Mutti, E., Séguret, M., Sgavetti, M., 1988. Sedimentation and Deformation in the Tertiary Sequences of the Southern Pyrenees: Field Trip 7: Parma, Italy. University of Parma, pp. $1-30$.

Nijman, W., Nio, S.D., 1975. The Eocene montanana delta (Tremp-Graus basin, provinces lerida and huesca, southern pyrenees, N. Spain). In: Rosell, J., Puigdefàbregas, C. (Eds.), 9th International Sedimentological Congress International Association of Sedimentologists. Nice.

Ogg, J., Lugowski, A., 2020. TS Creator Visualization of Enhanced Geologic Time Scale 2004 Database, Version 6.8. http://www.tscreator.org.

Payros, A., Tosquella, J., Bernaola, G., Dinarès-Turell, J., Orue-Etxebarria, X., Pujalte, V., 2009. Filling the north European early/middle Eocene (Ypresian/Lutetian) boundary gap: insights from the pyrenean continental to deep-marine record. Palaeogeogr. Palaeoclimatol. Palaeoecol. 280 (3-4), 313-332. https://doi.org/10.1016/j. palaeo.2009.06.018.

Pekar, S.F., Hucks, A., Fuller, M., Li, S., 2005. Glacioeustatic changes in the early and middle Eocene (51-42 Ma): shallow-water stratigraphy from ODP leg 189 site 1171 (south tasman rise) and deep-sea $\delta 180$ records. Bull. Geol. Soc. Am. 117 (7-8), 1081-1093. https://doi.org/10.1130/B25486.1.

Pickering, K.T., Corregidor, J., 2005. Mass-transport complexes (MTCs) and tectonic control on basin-floor submarine fans, middle Eocene, south Spanish Pyrenees. J. Sediment. Res. 75 (5), 761-783. https://doi.org/10.2110/jsr.2005.062.

Pickering, K.T., Bayliss, N.J., 2009. Deconvolving tectono-climatic signals in deepmarine siliciclastics, Eocene Ainsa basin, Spanish Pyrenees: seesaw tectonics versus eustasy. Geology 37 (3), 203-206. https://doi.org/10.1130/G25261A.1.

Pickering, K.T., Cantalejo, B., 2015. Deep-marine environments of the middle Eocene upper Hecho group, Spanish pyrenees: introduction. Earth Sci. Rev. 144, 1-9. https://doi.org/10.1016/j.earscirev.2015.02.001.

Piper, D.J.W., Normark, W.R., 2001. Sandy fans: from amazon to hueneme and beyond. Am. Assoc. Petrol. Geol. Bull. 85, 1407-1438.

Pohl, F., McCann, T., 2014. Architecture and depositional development of the Eocene deep-marine Morillo and coscojuela formations, aínsa basin, Spain. Geol. J. 49 (3), 221-238. https://doi.org/10.1002/gj.2511.

Posamentier, H.W., Vail, P.R., 1988. Eustatic controls on clastic deposition II-sequence and systems tract models, (42). In: Wilgus, C.K., Hastings, B.S., Kendall, C.G.S.C., Posamentier, H.W., Ross, C.A., Van Wagoner, J.C. (Eds.), Sea-Level Changes: an Integrated Approach, vol. 42. SEPM Special Publication, pp. 125-154.

Poblet, J., Muñoz, J.A., Travé, A., Serra-Kiel, J., 1998. Quantifying the kinematics of detachment folds using three-dimensional geometry: application to the Mediano anticline (Pyrenees, Spain). Geol. Soc. Am. Bull. 110 (1), 111-125. https://doi.org/ 10.1130/0016-7606(1998)110<0111:QTKODF>2.3.CO;2.

Puigdefàbregas, C., 1975. La Sedimentación Molásica en la Cuenca de Jaca. Pirineos 104, $1-188$.

Puigdefàbregas, C., Souquet, P., 1986. Tecto-sedimentary cycles and depositional sequences of the mesozoic and tertiary from the pyrenees. Tectonophysics 129 (1-4), 173-203. https://doi.org/10.1016/0040-1951(86)90251-9.

Puigdefàbregas, C., Muñoz, J.A., Vergés, J., 1992. Thrusting and foreland basin evolution in the Southern Pyrenees. In: McClay, K.R. (Ed.), Thrust Tectonics. Springer, Dordrecht, pp. 247-254.

Pujalte, V., Schmitz, B., 2005. Revisión de la estratigrafía del Grupo Tremp («Garumniense», Cuenca de Tremp-Graus, Pirineos meridionales). Geogaceta 38 (79), e82.

Remacha, E., Fernández, L.P., 2003. High-resolution correlation patterns in the turbidite systems of the Hecho group (South-Central pyrenees, Spain). Mar. Petrol. Geol. 20 (6-8), 711-726.

Romans, B.W., Castelltort, S., Covault, J.A., Fildani, A., Walsh, J.P., 2016. Environmental signal propagation in sedimentary systems across timescales. Earth Sci. Rev. 153, $7-29$. 
Rosenbaum, G., Lister, G.S., Duboz, C., 2002. Relative motions of africa, iberia and europe during alpine orogeny. Tectonophysics 359 (1-2), 117-129. https://doi.org/ 10.1016/S0040-1951(02)00442-0.

Roure, F., Chourkroune, P., 1998. Contribution of the Ecors seismic data to the Pyrenean geology: crustal architecture and geodynamic evolution of the Pyrenees. In: Damotte, B. (Ed.), The ECORS Pyrenean Deep Seismic Surveys, 1985-1994, vol. 173. Mémoires de la Société géologique de France, pp. 37-52.

Saltzman, M.R., Thomas, E., Gradstein, F.M., 2012. Carbon isotope stratigraphy. The geologic time scale 1, 207-232.

Schlager, W., 1993. Accommodation and supply—a dual control on stratigraphic sequences. Sediment. Geol. 86 (1-2), 111-136. https://doi.org/10.1016/0037-0738 (93)90136-S.

Schobben, M., Ullmann, C.V., Leda, L., Korn, D., Struck, U., Reimold, W.U., Ghaderi, A., Algeo, T., Korte, C., 2016. Discerning primary versus diagenetic signals in carbonate carbon and oxygen isotope records: an example from the Permian-Triassic boundary of Iran. Chem. Geol. 422, 94-107. https://doi.org/10.1016/j.chemgeo.2015.12.013.

Scholle, P.A., Arthur, M.A., 1980. Carbon isotope fluctuations in Cretaceous pelagic limestones: potential stratigraphic and petroleum exploration tool. AAPG Bull. 64 (1), 67-87. https://doi.org/10.1306/2F91892D-16CE-11D7-8645000102C1865D.

Scotchman, J.I., Bown, P., Pickering, K.T., BouDagher-Fadel, M., Bayliss, N.J., Robinson, S.A., 2015a. A new age model for the middle Eocene deep-marin Ainsa Basin, Spanish Pyrenees. Earth Sci. Rev. 144, 10-20. https://doi.org/10.1016/j. earscirev.2014.11.006.

Scotchman, J.I., Pickering, K.T., Sutcliffe, C., Dakin, N., Armstrong, E., 2015b. Milankovitch cyclicity within the middle Eocene deep-marine Guaso system, Ainsa basin, Spanish pyrenees. Earth Sci. Rev. 144, 107-121. https://doi.org/10.1016/j. earscirev.2015.01.007.

Séguret, M., 1972. Étude tectonique des nappes et séries décollées de la partie centrale du versant sud des Pyrénées - caractère synsédimentaire, rôle de la compression et de la gravité, Série géologie structurale, 2, France, vol. 155. Publications de l'Université des Sciences et Techniques du Languedoc (USTELA), Montpellier, France.

Sinclair, H.D., Gibson, M., Naylor, M., Morris, R.G., 2005. Asymmetric growth of the Pyrenees revealed through measurement and modeling of orogenic fluxes. Am. J. Sci. 305 (5), 369-406. https://doi.org/10.2475/ajs.305.5.369.

Sluijs, A., Zeebe, R.E., Bijl, P.K., Bohaty, S.M., 2013. A middle Eocene carbon cycle conundrum. Nat. Geosci. 6 (6), 429-434.

Thomson, K.D., Stockli, D.F., Clark, J.D., Puigdefàbregas, C., Fildani, A., 2017. Detrital zircon $(\mathrm{U}-\mathrm{Th}) /(\mathrm{He}-\mathrm{Pb})$ double-dating constraints on provenance and foreland basin evolution of the Ainsa Basin, south-central Pyrenees, Spain. Tectonics 36 (7), 1352-1375. https://doi.org/10.1002/2017TC004504.

Thomson, K.D., Stockli, D.F., Odlum, M.L., Tolentino, P., Puigdefàbregas, C., Clark, J., Fildani, A., 2019. Sediment provenance and routing evolution in the late cretaceous-eocene ager basin, south-central pyrenees, Spain. Basin Research. https://doi.org/10.1111/bre.12376.

Travé, A., Labaume, P., Calvet, F., Soler, A., 1997. Sediment dewatering and pore fluid migration along thrust faults in a foreland basin inferred from isotopic and elemental geochemical analyses (Eocene southern Pyrenees, Spain). Tectonophysics 282 (1-4), 375-398. https://doi.org/10.1016/S0040-1951(97)00225-4.

Tripati, A., Backman, J., Elderfield, H., Ferretti, P., 2005. Eocene bipolar glaciation associated with global carbon cycle changes. Nature 436 (7049), 341-346.

Vail, P.R., Mitchum Jr., R.M., Thompson III, S., 1977. Seismic stratigraphy and global changes of sea level, Part 3: relative changes of sea level from coastal onlap. In: Payton, C.E. (Ed.), Seismic Stratigraphy-Applications to Hydrocarbon Exploration, vol. 26. American Association of Petroleum Geologists Memoir, pp. 63-81.

Vinyoles, A., López-Blanco, M., Garcés, M., Arbués, P., Valero, L., Beamud, E., OlivaUrcia, B., Cabello, P., 2021. 10 Myr evolution of sedimentation rates in a deep marine to non-marine foreland basin system: tectonic and sedimentary controls (Eocene, Tremp-Jaca Basin, Southern Pyrenees, NE Spain). Basin Res. 33 (1), 447-477. https://doi.org/10.1111/bre.12481.

Voigt, S., 2000. Cenomanian-Turonian composite $\delta 13 \mathrm{C}$ curve for Western and Central Europe: the role of organic and inorganic carbon fluxes. Palaeogeogr. Palaeoclimatol. Palaeoecol. 160 (1-2), 91-104. https://doi.org/10.1016/S0031 0182(00)00060-2.

Weltje, G., de Boer, P.L., 1993. Astronomically induced paleoclimatic oscillations reflected in Pliocene turbidite deposits on Corfu (Greece): implications for the interpretation of higher order cyclicity in ancient turbidite systems. Geology 21 (4), 307-310. https://doi.org/10.1130/0091-7613(1993)021<0307:AIPORI>2.3.CO;2.

Westerhold, T., Röhl, U., 2013. Orbital pacing of Eocene climate during the Middle Eocene Climate Optimum and the chron C19r event: missing link found in the tropical western Atlantic. G-cubed 14 (11), 4811-4825. https://doi.org/10.1002/ ggge. 20293.

Whitchurch, A.L., Carter, A., Sinclair, H.D., Duller, R.A., Whittaker, A.C., Allen, P.A., 2011. Sediment routing system evolution within a diachronously uplifting orogen: insights from detrital zircon thermochronological analyses from the South-Central Pyrenees. Am. J. Sci. 311 (5), 442-482.

Zachos, J., Pagani, M., Sloan, L., Thomas, E., Billups, K., 2001. Trends, rhythms, and aberrations in global climate 65 Ma to present. Science 292 (5517), 686-693. 